\title{
Late Quaternary paleoceanography of the Eurasian Basin, Arctic Ocean
}

\author{
T. M. Cronin'1, T. R. Holtz, Jr. ${ }^{1}$, R. Stein², R. Spielhagen ${ }^{3}$, \\ D. Fütterer ${ }^{2}$, and $\mathrm{J}$. Wollenburg ${ }^{2}$
}

\begin{abstract}
We reconstructed late Quaternary deep (3000-4100 m) and intermediate depth (1000$2500 \mathrm{~m}$ ) paleoceanographic history of the Eurasian Basin, Arctic Ocean from ostracode assemblages in cores from the Lomonosov Ridge, Gakkel Ridge, Yermak Plateau, Morris Jesup Rise, and Amundsen and Makarov Basins obtained during the 1991 Polarstern cruise. Modern assemblages on ridges and plateaus between 1000 and $1500 \mathrm{~m}$ are characterized by abundant, relatively species-rich benthic ostracode assemblages, in part, reflecting the influence of high organic productivity and inflowing Atlantic water. In contrast, deep Arctic Eurasian basin assemblages have low abundance and low diversity and are dominated by Krithe and Cytheropteron reflecting faunal exchange with the Greenland Sea via the Fram Strait. Major faunal changes occurred in the Arctic during the last glacial/interglacial transition and the Holocene. Low-abundance, low-diversity assemblages from the Lomonosov and Gakkel Ridges in the Eurasian Basin from the last glacial period have modern analogs in cold, low-salinity, lownutrient Greenland Sea deep water; glacial assemblages from the deep Nansen and Amundsen Basins have modern analogs in the deep Canada Basin. During Termination 1 at intermediate depths, diversity and abundance increased coincident with increased biogenic sediment, reflecting increased organic productivity, reduced sea-ice, and enhanced inflowing North Atlantic water. During deglaciation deep Nansen Basin assemblages were similar to those living today in the deep Greenland Sea, perhaps reflecting deepwater exchange via the Fram Strait. In the central Arctic, early Holocene faunas indicate weaker North Atlantic water inflow at middepths immediately following Termination 1 , about $8500-7000$ year B.P., followed by a period of strong Canada Basin water overflow across the Lomonosov Ridge into the Morris Jesup Rise area and central Arctic Ocean. Modern perennial sea-ice cover evolved over the last 4000-5000 years. Late Quaternary faunal changes reflect benthic habitat changes most likely caused by changes in the import of cold, deepwater of Greenland Sea origin and warmer and middepth Atlantic water to the Eurasian Basin through the Fram Strait, and export of Arctic Ocean deepwater.
\end{abstract}

\section{Introduction}

Many aspects of Arctic Ocean history (among them changes in sea-ice cover, the location of grounded ice-sheets [Jones and Keigwin, 1988], glacial-interglacial shifts in biotic productivity [Stein et al., 1993], and the Arctic contribution to northern source deep water formation [Aagaard et al., 1985; Swift and Koltermann, 1988]) are important for determining the role of the Arctic in glacial-interglacial climatic cycles. Yet progress in late Quaternary Arctic paleoceanography has

\footnotetext{
${ }^{1}$ U.S. Geological Survey, Reston, Virginia

${ }^{2}$ Alfred Wegener Institute for Polar and Marine Research, Bremerhaven, Germany

${ }^{3}$ GEOMAR Research Center for Marine Sciences, University of Kiel, Kiel, Germany

Copyright 1995 by the American Geophysical Union.
}

Paper number 94PA03149.

0883-8305/95/94PA-03149\$10.00 been inhibited by a limited chronostratigraphic framework [Stein et al., 1994a], complex stable isotope signals from Arctic foraminifers [Spielhagen and Erlenkeuser, 1994], and disputed sedimentation rates [Clark et al., 1980; Gard, 1993]. This paper applies Arctic benthic ostracodes to bottom water paleoceanographic reconstruction of millennial-scale events that reflect changes in the relative strength of Arctic and Greenland Sea deep water and inflowing Atlantic water during the last glacial period, deglaciation (Termination 1), and the Holocene.

Despite prior controversy about sedimentation rates and age of Arctic sediments, recent studies of stable isotopes [Zahn et al.,1985; Jones and Keigwin, 1988; Kohler and Spielhagen, 1990], paleomagnetic stratigraphy [Bleil and Gard, 1989; Nowaczyk and Baumann, 1992], and micropaleontology [Gard, 1988] of Quaternary sediments from Arctic Ocean and Fram Strait cores have shown that Arctic sediments can be correlated to a standard timescale. The Arctic 91 expedition of the Polarstern [Futterer, 1992] obtained new cores from 1000 to $4000 \mathrm{~m}$ water depths from the Nansen, Amundsen, and Makarov Basins, the Yermak Plateau, Morris Jesup Rise, and Lomonosov Ridge (Figure 1), which to various degrees can be 


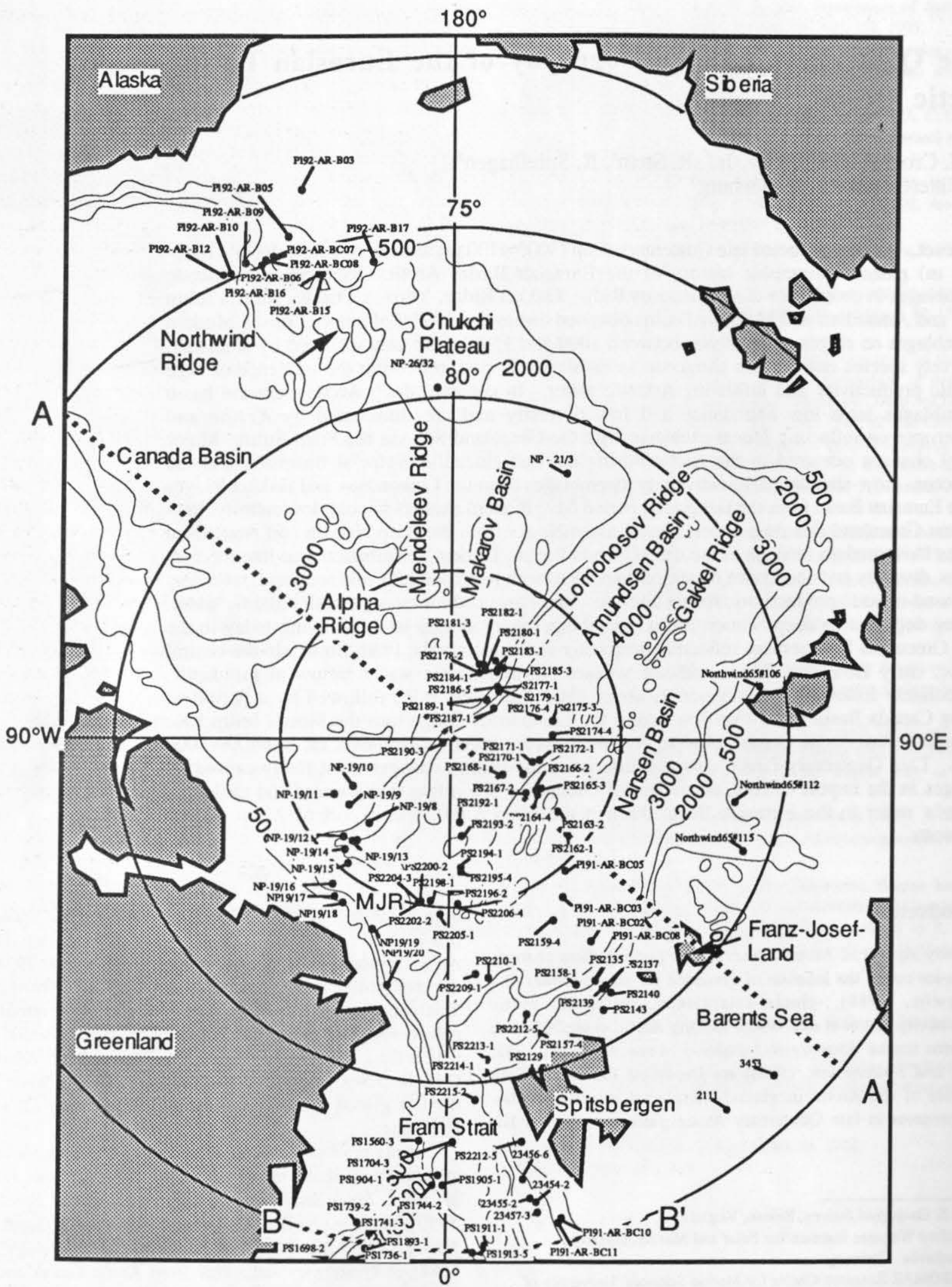

Figure 1. Map showing major features of the Arctic Ocean and the location of 111 core tops and eight multicores used in this study. Lines A-A' and B-B' are cross sections shown in Figures 2-6. Several modern core tops not shown on the map are located just south of the map area in the Greenland/Norwegian Sea (see Table A1 available on microfiche). 
dated and correlated to other regions based on paleomagnetic stratigraphy [Nowaczyk et al., 1995], accelerator mass spectrometer (AMS) dating and stable isotopes [Stein et al., 1993, 1994a, b], and nannofossil biostratigraphy [Gard, 1993]. These cores provide material for the present faunal and paleoceanographic study.

Ostracodes occur live throughout the Arctic Ocean and have potential as paleoceanographic tracers because they are common in Arctic sediments and many species are ecologically sensitive and limited to particular oceanic conditions and benthic habitats. In a preliminary studies, Joy and Clark [1977] found ostracodes were common in the upper 3 $\mathrm{cm}$ of core tops from the Canada Basin. Cronin et al. [1993, 1994] also found that ostracodes occur in Eurasian Basin core tops in water depths from the shelf to $>4000 \mathrm{~m}$ and that distinct shelf, slope, and deep basin assemblages characterize Arctic Ocean water masses. However, prior ostracode studies lacked quality box core data from deepwater environments of the Canada Basin, and very little was known about deepwater assemblages from areas off Spitsbergen and in the Nordic (Greenland and Norwegian) Seas. Further, although preliminary downcore data revealed faunal changes during the last glacial to interglacial transition [Cronin et al., 1994], sample spacing was not adequate to reconstruct paleoceanographic events of 1000 to 2000 years duration nor to determine which faunal events were Arctic-wide. The present paper overcomes these limitations through analyses of an extensive core top data set including material from the Arctic and Nordic Seas and the examination of centimeterspaced downcore samples dated where possible by AMS ${ }^{14} \mathrm{C}$ (AMS) dates and stable isotope stratigraphy.

Our first goal was to map the modern core top distribution of dominant ostracode species in the major intermediate and deep water masses in the Arctic and Greenland/Norwegian Seas for use in paleoceanographic reconstruction. To accomplish this, we expanded the Eurasian Basin core top database [Cronin et al., 1994] to include material obtained from inflowing Atlantic water near Spitzbergen (forming Arctic Intermediate Water), from the Norwegian and Greenland Seas (Greenland Sea deep water) and the Canada Basin (Canada Basin water) (Figure 1). We specifically wished to determine if there were differences between benthic faunas inhabiting warm, relatively saline Arctic Ocean deep water that forms through freezing and brine rejection on Arctic shelves and those inhabiting cold Greenland Sea deep water formed through open ocean convective processes. We also wanted to establish the faunal composition of assemblages that characterize Arctic Intermediate Water (AIW) (the Atlantic layer), to determine their affinities with extra-Arctic bathyal assemblages and which species indicate relatively warm water and/or high productivity.

By determining the modern faunal/water mass associations in the Arctic, we could then address our second goal, to identify changes in the relative strength of GSDW, AODW, and Atlantic Water in various parts of the Eurasian Basin during late Quaternary climatic changes. This entailed quantitative downcore faunal analyses of ostracode assemblages from cores dated by AMS-dating and stable isotope stratigraphy. We focused here on the faunal and oceanographic history during the last glacial period, the deglaciation of Termination 1 , and the Holocene.

\section{Modern Arctic Oceanography and Sediments}

\section{Arctic Oceanography}

The following brief summary of major Arctic and subarctic water masses is taken from several oceanographic sources for the Arctic Ocean [Aagaard, 1981, 1989; Aagaard et al., 1985; Anderson et al., 1994], the Greenland Sea/Fram Strait [Rudels, 1989; Aagaard et al., 1991; Rudels and Quadfasel, 1991], the Norwegian Sea [Swift and Koltermann, 1988], and the Barents Sea [Loeng, 1991]. The distribution of water masses in the Arctic and Greenland Sea/Fram Strait regions and profiles of temperature and salinity are illustrated in Figure 2. The Arctic Ocean is a well-stratified ocean characterized in the uppermost $50 \mathrm{~m}$ by a Polar Surface Water (PSW) $\left(-2\right.$ to $0^{\circ} \mathrm{C} ;<32$ to 34 $\mathrm{ppt}$ ): the main Arctic surface currents in this layer are the Transpolar Drift flowing from the Siberian shelf to the Fram Strait and the Beaufort Sea Gyre. PSW is underlain by a $100-\mathrm{m}$ thick halocline [Aagaard, 1981; Rudels, 1986] which buffers the permanent ice cover from the underlying warm Arctic Intermediate Water (lower AIW $=0^{\circ}$ to $2^{\circ} \mathrm{C}, 35 \mathrm{ppt}$; upper AIW $=-1^{\circ}$ to $+1^{\circ} \mathrm{C}, 34.7 \mathrm{ppt}$ ). AIW has its origin in the inflowing North Atlantic water which enters the Arctic via the West Spitzbergen Current $(100-600 \mathrm{~m})$ where temperatures are as high as $2^{\circ}$ to $3^{\circ} \mathrm{C}$ in its core and $2^{\circ}$ to $6^{\circ} \mathrm{C}$ in the Norwegian $\mathrm{Sea} / \mathrm{B}$ arents Sea area. This relatively warm saline water becomes slightly deeper and cooler (about $0.5^{\circ} \mathrm{C}$ ) by the time it reaches the Canada Basin. High-salinity (35.2 ppt) Mediterranean outflow water may also be influential in the Greenland-Norwegian Seas where it mixes with North Atlantic water [Reid, 1979] and thus may contribute to deep water formed there. Several ostracode species inhabiting Arctic middepth environments are closely related and perhaps conspecific with Mediterranean species, indicating a faunal link between Arctic and Mediterranean bathyal habitats (see below).

At depths below about $800 \mathrm{~m}$, Arctic Ocean deep water includes Eurasian Basin deep water (EBDW) $\left(-0.6^{\circ} \mathrm{C}\right.$ to $-1.0^{\circ} \mathrm{C}$, $34.93 \mathrm{ppt})$, which has similar temperature and salinity characteristics to deep Norwegian Sea water, and Canada Basin deep water (CBDW) $\left(-0.3^{\circ} \mathrm{C}\right.$ to $\left.-0.5^{\circ} \mathrm{C}, 34.95 \mathrm{ppt}\right)$, which is slightly warmer and more saline. The Eurasian and Canada Basin deep waters are separated from each other by the Lomonosov Ridge $(<2000 \mathrm{~m})$, a major barrier to deepwater exchange, whereas the Eurasian Basin is connected to Greenland Sea deep water $\left(-1.2^{\circ} \mathrm{C}\right.$ to $\left.-1.4^{\circ} \mathrm{C}, 34.90 \mathrm{ppt}\right)$ by the deep ( $>2500 \mathrm{~m}$ ) Fram Strait. Strong middepth boundary currents run counterclockwise around the Eurasian Basin between about 400 and $1000 \mathrm{~m}$ [Aagaard, 1989]. In the more isolated Canada Basin, boundary currents also run counterclockwise but are weaker and shallower.

AODW contributes to northern source deepwater formation by mixing with cold fresh Greenland Sea deep water after exiting through the Fram Strait [Aagaard et al., 1985; Aagaard, 1989; Aagaard et al., 1991; Rudels, 1989; Rudels and Quadfasel, 1991]. In turn, GSDW is a component of Norwegian Sea water which spills over to form a major part of North Atlantic deep water (NADW). It is important to emphasize the distinction between Arctic Ocean deep water formed mainly through freezing and brine rejection on Arctic shelves versus open ocean deepwater formation in the Greenland Sea. The warmer, more saline deep water 
A

A ARCTIC OCEAN

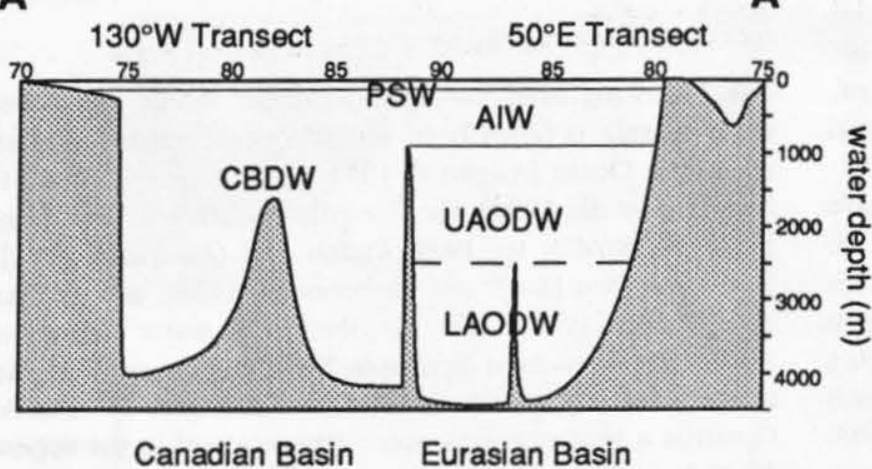

B

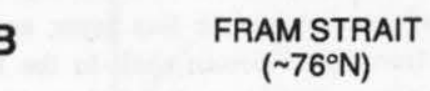

TEMPERATURE

$\left({ }^{\circ} \mathrm{C}\right)$

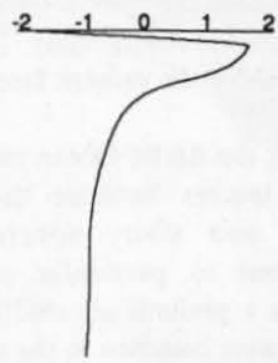

B'
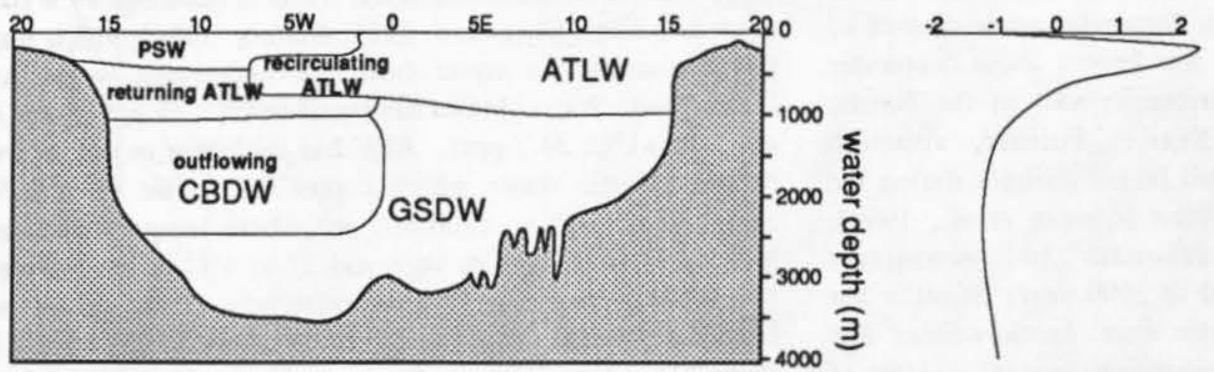

SALINITY

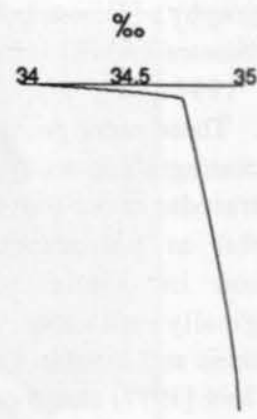

a

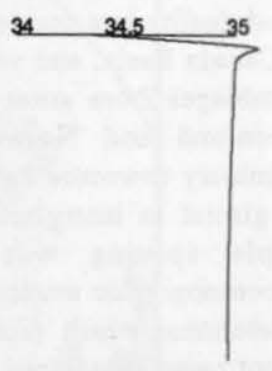

Figure 2. (a) Cross section of Arctic Ocean from $A-A^{\prime}$ in Figure 1 showing generalized water mass stratification and generalized temperature and salinity profiles. ATLW, Atlantic water; CBDW, Canadian Basin deep water; GSDW, Greenland Sea deep water; PSW, Polar surface water. (b) Cross section of Fram Strait region from B-B' in Figure 1 schematically showing major water masses (modified from Rudels [1989]) and generalized temperature and salinity profiles. AIW, Atlantic intermediate water; LAODW, lower Arctic Ocean deep water; UAODW, upper Arctic Ocean deep water.

originating on Arctic shelves and sinking through gravitational plumes is also an important source of water in the Greenland Sea. Aagaard et al. [1991] refer to this middepth salinity maximum as Type 1 which occurs as Arctic Ocean outflow about 1200 to $2000 \mathrm{~m}$ water depth in the western Fram Strait. Anderson et al. [1994] traced this water mass leaving the Canada Basin across the southern Lomonosov Ridge, crossing the Morris Jesup Rise and exiting the Arctic in the western Fram Strait as a boundary current along the Greenland Slope. In this way, exported deep water from the Arctic contributes to the overall budget of northern source deep water. Below we will present evidence that Arctic Ocean deep water has a characteristic ostracode fauna and that its influence in the Eurasian Basin may have varied during the late Quaternary.

\section{Arctic Surface Sediments}

The carbonate content of Arctic Ocean surface sediments is relatively low $(<10 \%)$, although on the Yermak Plateau, Gakkel Ridge, and eastern Lomonosov Ridge, it can reach 10$20 \%$ and on the Morris Jesup Rise about 30\% [Stein et al., 1994c]. Total organic carbon in surface sediments is relatively high $(0.5-2 \%)$ compared to open-ocean marine sediments, mainly due to the greater supply of terriginous input. In areas of reduced sea ice, such as northwest of Svalbard, there is increased preservation of marine organic material due to increased surface productivity [Pagels, 1991]. Arctic sediments also contain abundant benthic and planktonic foraminifera, ostracodes, molluscs, and other organisms, which are not significantly affected by dissolution above the lysocline near $4700 \mathrm{~m}$ [Pagels, 1991].

\section{Material and Methods}

\section{Core Top Samples}

In order to obtain as complete coverage of all major deep and intermediate depth water masses as possible, the core top database includes the 40 core tops from box cores from the 1991 Polarstern cruise and an additional 71 core tops from Polarstern and Meteor cruises to the Greenland/Norwegian Seas, the 1992 cruise of the Polarstar to the Northwind Ridge (provided by R. Z. Poore, U.S. Geological Survey (USGS)), and ice island core tops from the Mendeleyev and Lomonosov Ridge (provided by Leonid Polyak, Ohio State University), for a total of 111 stations (Figure 1 , appendix Table $\mathrm{Al}^{1}$ ). Appendices 2-4 contain core top and downcore species census data and modern analog technique analyses (see below). All 
appendices are available electronically through the National Geophysical Database Center (NGDC), Boulder, Colorado (at paleo@mail.ngdc.noaa.gov) and the USGS Global Change program.

Ideally, core top assemblages should represent a near life assemblage with minimal temporal or spatial mixing. Therefore we studied material only from the upper $0-1 \mathrm{~cm}$ of box cores and multicores. In the Eurasian Basin, sedimentation rates vary but are generally about 0.5-3 $\mathrm{cm} / 1000$ yr [Gard, 1993; Stein et al., 1993]. Thus most core top assemblages from the uppermost centimeter represent a time interval of less than 1000 to 2000 years. Low sedimentation rates $(1-5 \mathrm{~mm} / 1000 \mathrm{yr})$ in parts of the Canada Basin [Scott et al., 1989; Poore et al., 1993] mean that core tops from those regions may have experienced a greater degree of temporal mixing so we did not include ostracode data from the top $3 \mathrm{~cm}$ of Canada Basin ice island cores [Joy and Clark, 1977; Jones et al., 1994].

In general, Polarstern core top samples from the 1991 cruise contained in situ ostracode assemblages showing little evidence of temporal or spatial mixing. Ice-rafted specimens of shelf species were very rare in only a few core tops [Cronin et al., 1994]. Furthermore, multicore surface samples from the same sites as Polarstern box core samples were located sometimes yielded ostracodes with appendages preserved, demonstrating a species lived in a particular benthic habitat. (Appendages and soft parts have also been observed in most core tops from the 1993 Polarstern cruise to the Barents and Laptev Seas (T.M. Cronin, unpublished data, 1994).

\section{Core Selection and Downcore Faunal Analyses}

We analyzed ostracodes from eight multicores and five box cores that represent the major ridges and basins in the Eurasian Basin (Lomonosov and Gakkel Ridges, Yermak Plateau, Morris Jesup Rise and Amundsen, Nansen, and Makarov Basins) to reconstruct the late Quaternary faunal and paleoceanographic history of the deep and middepth Arctic Ocean (Figure 1, Table 1). These cores were selected because they are located on topographic highs away from the influence of turbidites, they had isotope stratigraphy, and in some cases AMS radiocarbon dates. Because bioturbation and burrowing are common in brown muds blanketing the Arctic floor and can disturb sediments as much as 2 to $36 \mathrm{~cm}$ in the deep basins [Fütterer, 1992; Phillips, 1994], we examined faunal sequences from both the box core and the multicore obtained from the same site (i.e., sites PS2179 and PS2185, Table 1) or from two multicores from nearby sites (PS2200/PS2202 and PS2163/PS2206, Table 1). In doing so, we were able to establish the reproducibility of faunal patterns within a region, which we would not expect to see if bioturbation has significantly altered the original sequence of faunal assemblages. We also studied a transect of five box cores and two multicores across the Lomonosov Ridge between about

Appendix Tables A1-A4 are available on microfiche. Order from the American Geophysical Union, 2000 Florida Avenue, N.W., Washington, DC 20009. Document P94-002; \$2.50. Payment must accompany order.
1000 and $2000 \mathrm{~m}$ water depth to more firmly establish the faunal sequence in the central Arctic Ocean.

AMS dates are available from three multicores (PS2163-2, PS2170-4, and PS2206) [Stein et al., 1994b] and carbon and oxygen stable isotope stratigraphic data for all cores [Stein et al., 1993, 1994a]. Paleomagnetics [Nowaczyk et al., 1995], and nannofossil biostratigraphy [Gard, 1993] also provide age control (see below).

\section{Ostracode Taxonomy}

We followed the taxonomy of Whatley and Coles [1987] and Whatley and Eynon [1995] with slight modifications mentioned by Cronin et al. [1994]. The genus Polycope, which has about eight or nine species in the Arctic Ocean, was not separated into species, however the abundance of this genus coincides with organic-rich sediment, inferred highproductivity characteristic of interglacial periods in the Arctic (see below). Acetabulastoma arcticum Schornikov is a species that lives as a parasite on amphipods which live in the Arctic Ocean at the sea-ice/water interface. This species was referred to as Paradoxostoma rostratum Sars by Baker and Wong [1968].

\section{Results}

\section{Modern Ostracode Species and Water Masses}

We identified 22 key ostracode taxa (Table 2) useful for paleoceanographic study in the intermediate and deep Arctic Ocean on the basis of assemblages in 111 core tops. Contour plots of the percentages of 18 taxa in core top samples are shown in two cross sections (Figures 3-6), one across the Arctic Ocean from the Barents Sea Shelf to the Bering Strait (section $A-A^{1}$ in Figure 1), the other in the Fram Strait/Greenland Sea region (B-B ${ }^{1}$ in Figure 1). These data provide first approximations of the geographic and bathymetric distribution of ostracode species and their association with Arctic and Greenland/Norwegian Sea water masses. Before proceeding, a few caveats about the use of ostracodes for paleoceanography and reconstructing water mass history are required. In contrast to their use in continental shelf environments, the application of ostracode species to reconstruct deep-sea environments is still developing. Although the species distributions shown in Figures 3-6 illustrate clear associations between species and distinct water masses, the actual factors responsible for limiting these species' distributions are not always clear. In general, we assume, in lieu of experimental data, that one or more characteristics of a particular water mass such as temperature, dissolved oxygen, nutrients, etc. are responsible for the species assemblage found in that environment [Dingle et al., 1990]. In some cases we have good evidence from several areas which environmental parameter leads to the dominance of a particular species, such as the association of Henryhowella asperrima with high levels of dissolved oxygen. The significance of Acetabulastoma arcticum as an indicator of sea-ice also seems reasonable in light of available evidence, although there are also shallow water species of Acetabulastoma with completely different ecology [Schornikov, 1970]. As additional ecological data become available, the usefulness of various species for estimating past 
Table 1. Core Data for 1991 Polarstern Arctic Ocean Ostracode Analyses

\begin{tabular}{llrrrrr}
\hline Site & Region & Latitude $\left({ }^{\circ} \mathrm{N}\right)$ & Longitude $\left({ }^{\circ}\right)$ & WD $(\mathrm{m})$ & Core Type & Sampling, cm \\
\hline PS2163-2 & Gakkel Ridge & 86.24 & 59.08 & 3047 & multicore & 1 \\
PS2170-1 & Amundsen Basin & 87.59 & 60.26 & 4226 & multicore & 1 \\
PS2177-1 & Lomonosov Ridge & 88.04 & 134.31 & 1388 & boxcore & 5 \\
PS2178-2 & Makarov Basin & 88.00 & 159.08 & 4009 multicore & 1 \\
PS2179-1 & Lomonosov Ridge & 87.75 & 138.01 & 1230 & boxcore & 5 \\
PS2179-3 & Lomonosov Ridge & 87.75 & 138.01 & 1228 multicore & 1 \\
PS2184-1 & Lomonosov Ridge & 87.63 & 148.05 & 1640 boxcore & 5 \\
PS2185-4 & Lomonosov Ridge & 87.63 & 148.05 & 1051 multicore & 1 \\
PS2185-3 & Lomonosov Ridge & 87.53 & 144.13 & 1051 boxcore & 5 \\
PS2186-5 & Lomonosov Ridge & 88.52 & 140.16 & 1996 boxcore & 5 \\
PS2200-2 & Morris Jesup Rise & 85.33 & -14.00 & 1074 multicore & 1 \\
PS2202-2 & Morris Jesup Rise & 85.11 & -14.13 & 1083 multicore & 1 \\
PS2206-4 & Gakkel Ridge & 85.06 & -13.04 & 3899 & multicore & 1 \\
PS2212-5 & Yermak Plateau & 82.07 & 15.26 & 2485 multicore & 1 \\
\hline
\end{tabular}

See Fütterer [1992] for core information; Stein et al. [1994a] for stable isotope and AMS data. WD, Water Depth (meters), Sampling, Sampling interval (cm).

environments will improve. A second assumption is that the ecology of a particular species does not change much with time. Because we are concerned here with the last 20,000 years or so, this assumption does not pose a problem.

Arctic Intermediate Water-North Atlantic Water. Several ostracode species serve as indicators for this middepth water mass characterized by relatively high temperatures $\left(\geq 0^{\circ} \mathrm{C}\right)$ and high salinity. Cytheropteron testudo, Cytheropteron cronini, Cytheropteron pseudoinflatum, and Eucytherura delineata reach their highest proportions in this layer in the Fram Strait and Arctic Ocean (Figures 3 and 4). C. testudo, the well-known "cold guest" in the Mediterranean that has been used as a marker for the Pliocene/Pleistocene boundary [see Bonaduce and Sprovieri, 1984], is particularly important as it reaches $4-8 \%$ in the eastern Fram Strait near $1000 \mathrm{~m}$ at the entrance to the Arctic and $8-12 \%$ in the western Fram Strait near $2000 \mathrm{~m}$. In the Eurasian Basin, it is common at less than $1200 \mathrm{~m}$, and it is notably rare in the Canada Basin. This species (or closely related forms) occur in many of the world's oceans at bathyal depths. Eucytherura delineata is another important middepth species that is most common in core tops from near Spitzbergen, in very low percentages on the Lomonosov Ridge, but is absent in the Canada Basin core tops. Pedicythere neofluitans (Figure 6) characterizes Upper Arctic Ocean deep water but is not a major component of lower AODW or CBDW. The occurrence of these species in downcore samples signifies strong inflow of North Atlantic water into the Arctic.

Several middepth taxa have obvious taxonomic affinities to Mediterranean bathyal ostracode assemblages. These include Eucytherura delineata, Pedicythere neofluitans, Cytheropteron testudo, Nannocythere delicata, and several species of Polycope [Joy and Clark, 1977]. Nannocythere delicata (Figure 3) requires additional taxonomic study; however, it resembles species of the genus Rectobuntonia in the Mediterranean. Bathyal environments along the IcelandFaroes Rise and the Norwegian Sea presumably provided a migration route for these species, but the timing of their first appearance in Arctic regions is not yet known.
Greenland Sea Deep Water-Eurasian Basin Deep Water. Several species inhabit deep Greenland Sea water and apparently disperse easily through the Fram Strait into the Eurasian Basin. Krithe cf. pernoides is one of the dominant deep Arctic ostracodes, reaching proportions $>50 \%$ in lower Arctic and Greenland Sea deep water (Figure 5). Eucythere sp. occurs exclusively in deep GSDW core tops. The occurrence of Eucythere and Krithe cf. pernoides in glacial-age sediments from middepths in the central Arctic Ocean suggests a shift in the influence of GSDW from the deep basins of the central Arctic during interglacials to the intermediate depths during glacials (see below). Cytheropteron alatum is also a typical deep Greenland Sea species that occurs in moderate amounts in the Eurasian Basin deep water (Figure 5), but the Lomonosov Ridge seems to act as a barrier limiting its widespread dispersal in the Makarov Basin. Henryhowella asperrima is a cosmopolitan species living in high percentages in the world's oceans below the thermocline and oxygen minimum layer in cold, well-ventilated water [Dingle et al., 1990; Cronin, 1983]. In Arctic core top samples it predominates in upper GSDW (2100-2800 $\mathrm{m}$ ) and upper CBDW (Figure 4). The sample PS1736 from $3500 \mathrm{~m}$ in the Greenland Sea represents a typical assemblage of Eucythere sp., $K$. cf. pernoides, $C$. alatum, and Henryhowella asperrima. Krithe minima also reaches high proportions in the lower Greenland Sea deep water and the deep Eurasian Basin.

Arctic Ocean Deep Water and Sea-ice indicators. Cytheropteron bronwynae is the only common deep ostracode species endemic to the Arctic, and it is typically abundant in lower AODW (Figure 6). It occurs on both sides of the Lomonosov Ridge but does not occur in the Greenland Sea. Cytheropteron carolinae is also a dominant lower AODW species that inhabits the deep Greenland Sea (Figure 5) as well as the deep North Atlantic.

In upper AODW near the transition with AIW, Acetabulastoma arcticum, Polycope spp. (Figure 6), and Pseudocythere caudata (Figure 4) are predominant in the open ocean Eurasian Basin. They are almost never found in the deepest Arctic basins below $3000 \mathrm{~m}$. Acetabulastoma arcticum 
Table 2. Arctic Ostracode Species and Associated Water Masses

\begin{tabular}{|c|c|c|c|c|}
\hline Taxon & Main Water Mass & $\begin{array}{l}\text { Greenland/Norwegian Seas/ } \\
\text { Fram Strait }\end{array}$ & Arctic Ocean & Comments \\
\hline Cytheropteron cronini & ATLW,AIW & WFS $(500 \mathrm{~m}), \mathrm{EFS}(1500 \mathrm{~m})$ & $\begin{array}{l}\text { Arctic Ocean Ridges \& Plateaus } \\
(<800 \mathrm{~m})\end{array}$ & \\
\hline $\begin{array}{l}\text { Cytheropteron } \\
\text { pseudoinflatum }\end{array}$ & ATLW,AIW & $\begin{array}{l}\text { EFS }(500-2500 \mathrm{~m}) \text {, } \\
\text { WFS }(500-1000 \mathrm{~m})\end{array}$ & $\mathrm{EB}(<1500 \mathrm{~m})$ & ATLW, MW? influence \\
\hline Cytheropteron testudo & ATLW,AIW & WFS $(500-1800 \mathrm{~m})$ & EB $(500-1200 \mathrm{~m}), \mathrm{CB}$ rare & ATLW, MW? influence \\
\hline Eucytherura delineata & ATLW,AIW & $\begin{array}{l}\text { EFS }(1000-1500 \mathrm{~m}) \text {, } \\
\text { WFS }(500-1000 \mathrm{~m})\end{array}$ & MJR, YP (400-1500 m) & ATLW, MW? influence \\
\hline Nannocythere delicata & $\begin{array}{l}\text { ATLW,LAIW, } \\
\text { UAODW }\end{array}$ & WFS $(500-2300 \mathrm{~m})$ & MB, CB, NB rare, $(1000-2500 \mathrm{~m})$ & ATLW, MW? influence \\
\hline Thaerocythere crenluata & ATLW & $\cdots$ & $(<1000 \mathrm{~m})$ & generally shelf \\
\hline Muellerina abyssicola & ATLW & $\ldots$ & $(<1000 \mathrm{~m})$ & generally shelf/slope \\
\hline Pedicythere neofluitans & UAODW & & $(1000-2500 \mathrm{~m})$ & Mediterranean water influence \\
\hline Krithe minima & LGSDW & Central $(>2400 \mathrm{~m})$ & $\begin{array}{l}\text { rare NB }(2500-3500 \mathrm{~m}) \text {, } \\
\text { CB }(1000-2500 \mathrm{~m})\end{array}$ & \\
\hline Eucythere sp. & LGSDW & $\mathrm{EFS}(>1500 \mathrm{~m})$ & NB only near FS & cold well vents, GSDW \\
\hline Henryhowella asperrima & UGSDW,UCBDW & WFS $(2000-3000 \mathrm{~m})$ & $\begin{array}{l}\text { NB }(2000-3000 \mathrm{~m}), \mathrm{AB}(1200-1400 \mathrm{~m}) \\
\mathrm{CB}(1300-2300 \mathrm{~m})\end{array}$ & higher oxygenated mid-depth \\
\hline $\begin{array}{l}\text { Krithe cf. pernoides } \\
\text { Pseudocythere caudata }\end{array}$ & $\begin{array}{l}\text { LGSDW,LAODW } \\
\text { ATLW,UGSDW, } \\
\text { UAODW,AIW }\end{array}$ & $\begin{array}{l}(>1000 \mathrm{~m}) \\
\text { NFS }(1500-2200 \mathrm{~m})\end{array}$ & $\begin{array}{l}\text { CB }(500-4000 \mathrm{~m}), \text { MB rare, EB }(>1000 \mathrm{~m}) \\
\text { NB }(400-1200 \mathrm{~m}), \mathrm{CB} \text { absent, } \\
\text { MB }(1500-2500 \mathrm{~m}), \mathrm{AB}(1500-2000 \mathrm{~m})\end{array}$ & cold well vent., GSDW \\
\hline Cytheropteron alatum & LGSDW,EBDW & WFS Common & $\begin{array}{l}\text { EBDW }(>3700,500-2500 \mathrm{~m}) \\
\text { MB rare }(>1400 \mathrm{~m})\end{array}$ & cold well vent., GSDW \\
\hline Cytheropteron carolinae & AODW & $\begin{array}{l}(500-3500 \mathrm{~m}) \\
\text { WFS }>\text { EFS (Rare) }\end{array}$ & EB $(>3000 \mathrm{~m}), \mathrm{CB}(2000-3000 \mathrm{~m})$ & maybe two subspecies \\
\hline Cytheropteron bronwynae & AODW & $\ldots$ & $(>1500 \mathrm{~m})$ & endemic Arctic species \\
\hline $\begin{array}{l}\text { Bythoceratina scaberrima } \\
\text { Cytheropteron hamatum }\end{array}$ & $\begin{array}{l}\text { UAODW } \\
\text { UCBDW }\end{array}$ & WFS only, ${ }^{\cdots}$ & $\begin{array}{l}\text { MJR, LR }(1000-2500 \mathrm{~m}) \\
\text { MB (1000-3400 m), EB rare-absent }\end{array}$ & outflowing Arctic water along boundary \\
\hline & & $(1000-2500 \mathrm{~m})$ & & $\begin{array}{l}\text { currents, MJR-Greenland Slope } \\
\text { Boundary Current }\end{array}$ \\
\hline Acetabulastoma arcticum & UEBDW,MBDW & $\ldots$ & $\begin{array}{l}\text { NB, AB, MB }(1000-3500 \mathrm{~m}) \text {, } \\
\text { CB rare, Open Ocean }\end{array}$ & $\begin{array}{l}\text { parasitic on amphipod, sea ice } \\
\text { indicator }\end{array}$ \\
\hline Polycope spp. & UAODW & $\ldots$ & $(1000-3000 \mathrm{~m})$ & $\begin{array}{l}\text { organic rich, fine grained sediment; } \\
\text { reduced sea ice and increased } \\
\text { productivity }\end{array}$ \\
\hline Argilloecia sp. & UCBDW,UAODW & $(500-2500 \mathrm{~m})$ & $\begin{array}{l}\text { NB }(<2000 \mathrm{~m}), \mathrm{CB}, \mathrm{MB}(500-2300 \mathrm{~m}) \text {, } \\
\text { Ocean Margins }\end{array}$ & \\
\hline
\end{tabular}

Abbreviations: U, upper; L, lower; AODW, Arctic Ocean Deep Water; CBDW, Canadian Basin Deep Water; AIW, Arctic Intermediate Water; NB, Nansen Basin; CB, Canadian Basin; MB, Makarov Basin, AB, Amundsen Basin; EB, Eurasian Basin; MJR, Morris Jesup Rise; LR, Lomonosov Ridge; YP, Yermak Plateau; MW, Mediterranean Water. 
FRAM STRAIT

B $\quad\left(\sim 76^{\circ} \mathrm{N}\right)$
ARCTIC OCEAN

B' A $130^{\circ} \mathrm{W}$ Transect $50^{\circ} \mathrm{E}$ Transect A
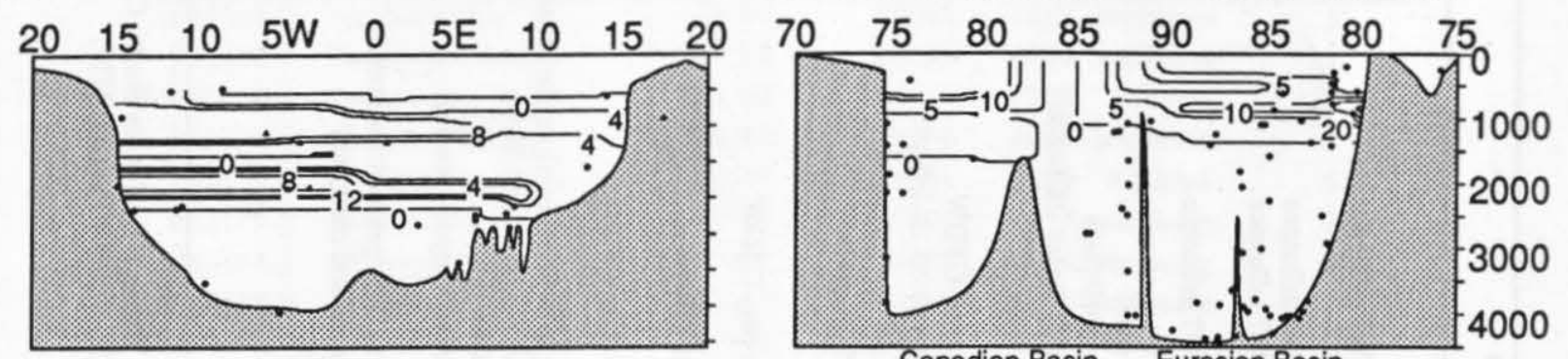

Cytheropteron testudo
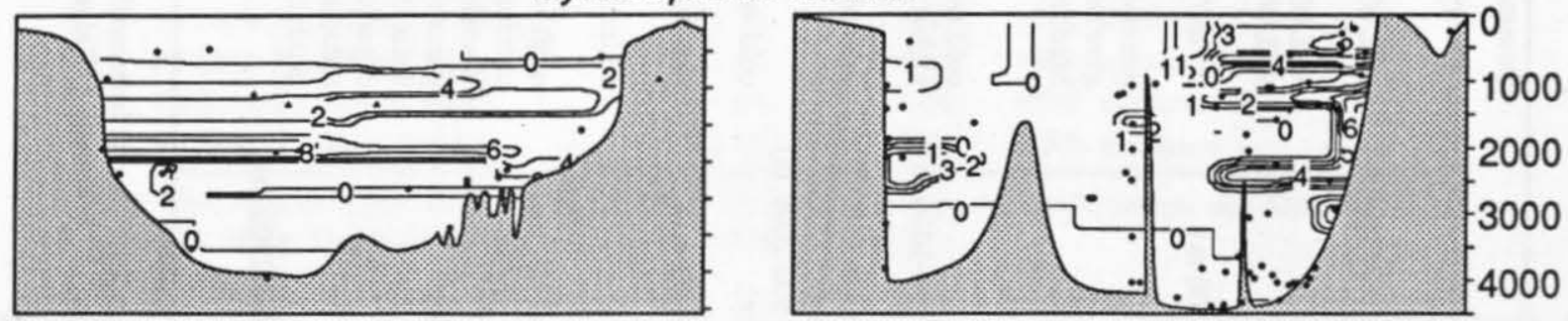

Argilloecia sp.
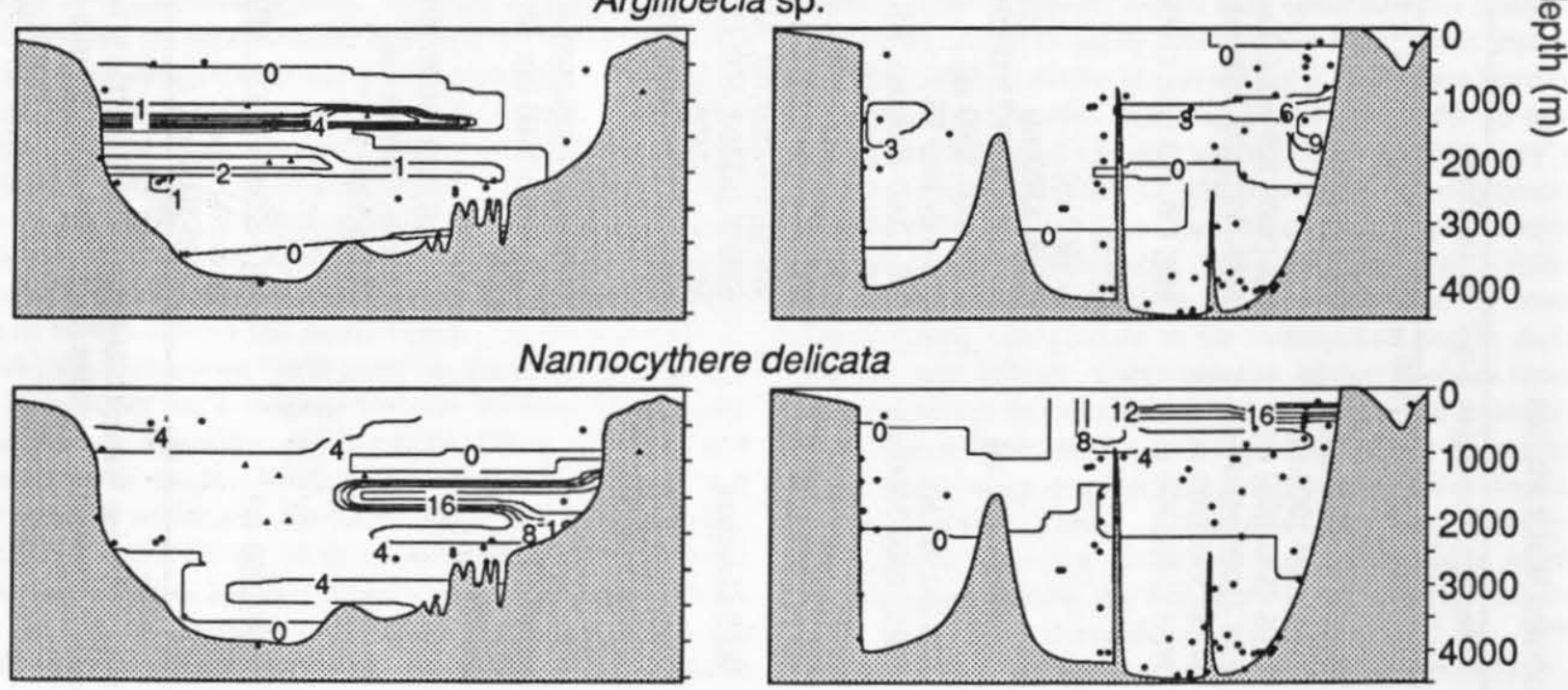

Cytheropteron pseudoinflatum

Figure 3. Contour plots of percentage of occurrences of Cytheropteron testudo, Argilloecia sp., Nannocythere delicata, and Cytheropteron pseudoinflatum in the Fram Strait region and the Arctic Ocean. Black dots show core top stations; diamonds are northern Fram Strait region stations.

and Polycope spp. are especially rare in core tops from along the margins of the Arctic. The genus Acetabulastoma represents a special ecological situation in that most of its species are parasitic on Amphipoda [Baker and Wong, 1968; Schornikov, 1970; Whatley, 1982]. In the central Arctic Ocean, this fact has special paleoceanographic significance because $A$. arcticum, the species commonly found in our material, has been described living as a parasite on two amphipods (Gammarus wilkitzkii and Gammaracanthus loricatus) which inhabit the ice-water margin below sea ice in the central Arctic at the Fletcher Island T-3 Ice island [Barnard,
1959; Baker and Wong, 1968]. Its occurrence in significant numbers $(2-12 \%)$ in the uppermost few centimeters representing in Arctic cores is postulated to signify the presence of surface sea-ice conditions (see below). It is not yet clear why this species is absent below 3000 -m water depth, unless its shell is more susceptible to dissolution that other taxa.

Polycope also has a distinct morphology and ecology; it is is often associated with fine-grained, organic-rich sediment in the Mediterranean and also in the Arctic where it comprises more than $30 \%$, sometimes more than $50 \%$, of assemblages 


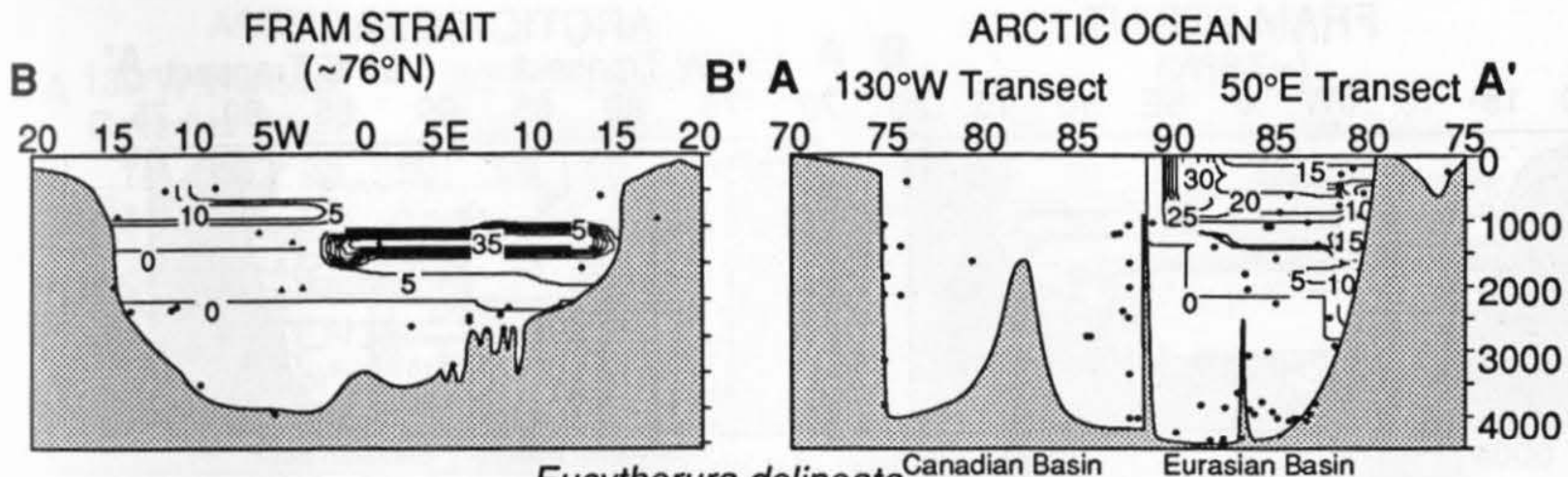

\section{Eucytherura delineata ${ }^{\text {Canadian Basin }}$ Eurasian Basin}
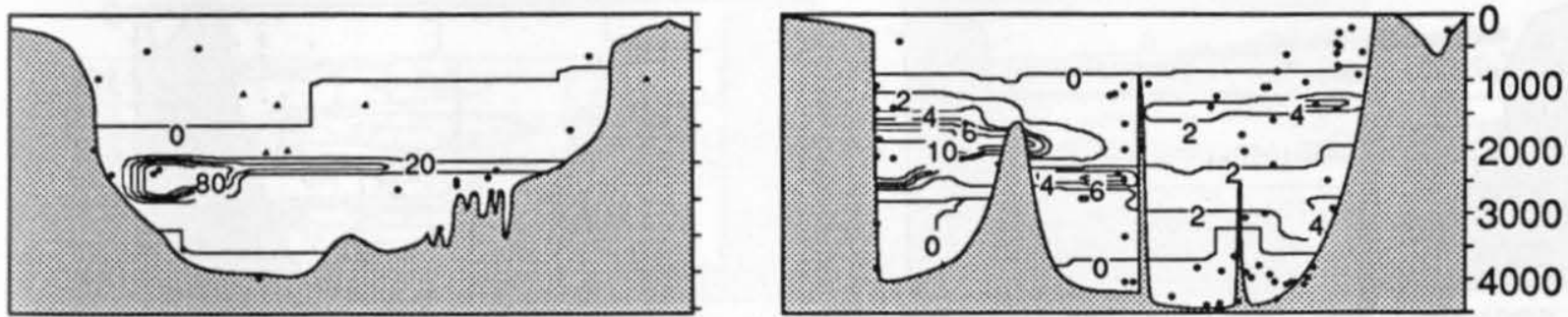

Henryhowella asperrima
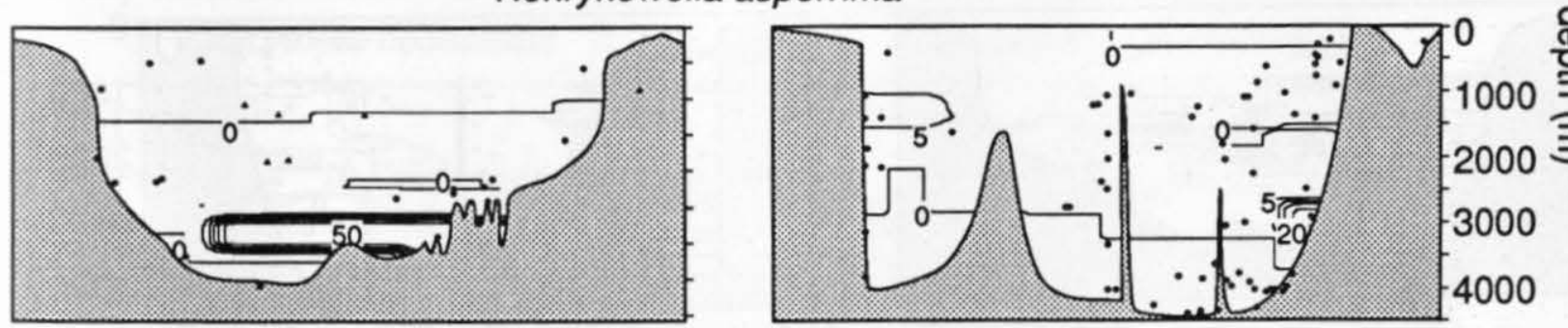

Krithe minima
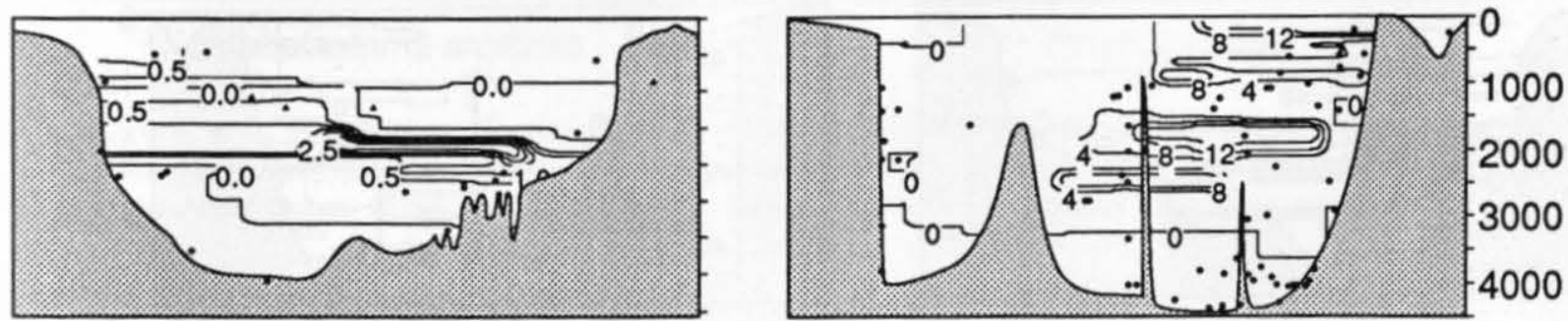

Pseudocythere caudata

Figure 4. Contour plots of percentage of occurrences of Eucytherura delineata, Henryhowella asperrima, Krithe minima, and Pseudocythere caudata in the Fram Strait region and the Arctic Ocean. Black dots show core top stations; diamonds are northern Fram Strait region stations.

near $1000-1500 \mathrm{~m}$ on the Lomonosov Ridge and Morris Jesup Rise (Figure 6). This genus becomes progressively less common in deeper water. Its dominance at the boundary of uppermost AODW and AIW makes it a useful indicator of the relative strength of Atlantic in the Arctic near the AODW/AIW boundary.

Pseudocythere caudata characterizes lower Atlantic water, upper Greenland Sea deep water and Arctic Intermediate water but does not occur in the deepest basins nor in the Canada Basin. It occurs commonly in greatest proportions with Acetabulastoma arcticum and Polycope spp. We interpret the core top patterns to indicate that $P$. caudata prefers Arctic environments where cold, saline water produced on shelves of the Eurasian Basin spills onto the slopes where it mixes with inflowing Atlantic water. Cytheropteron carolinae and $C$. alatum also occur frequently in these environments. These distinct upper AODW assemblages are generally limited to the Eurasian Basin.

Upper Canada Basin Deep Water. Cytheropteron hamatum reaches its greatest proportions on the Canada Basin side of the Lomonosov Ridge and comprises more than $10 \%$ of assemblages in the western Fram Strait along the Greenland 

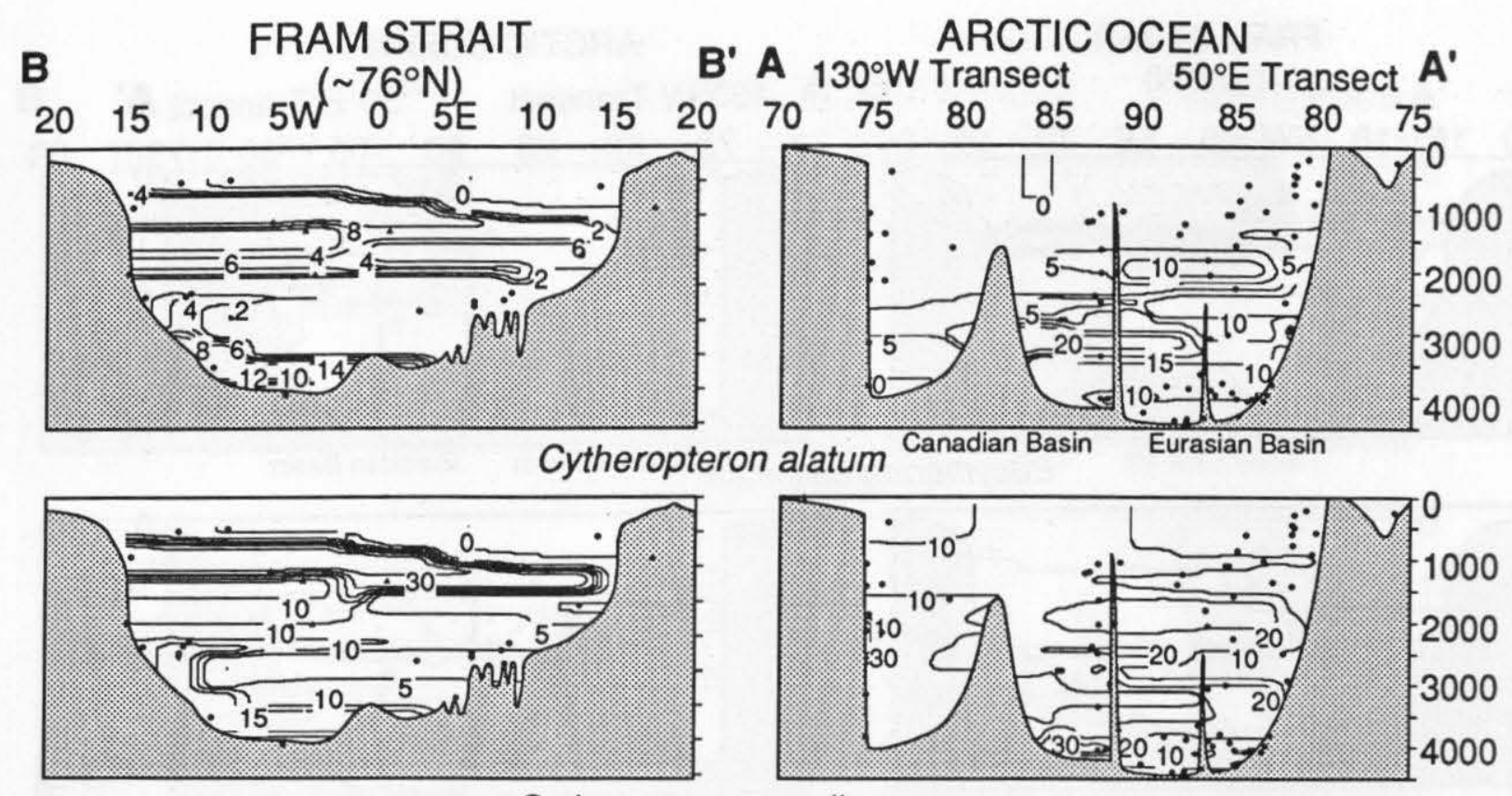

Cytheropteron carolinae
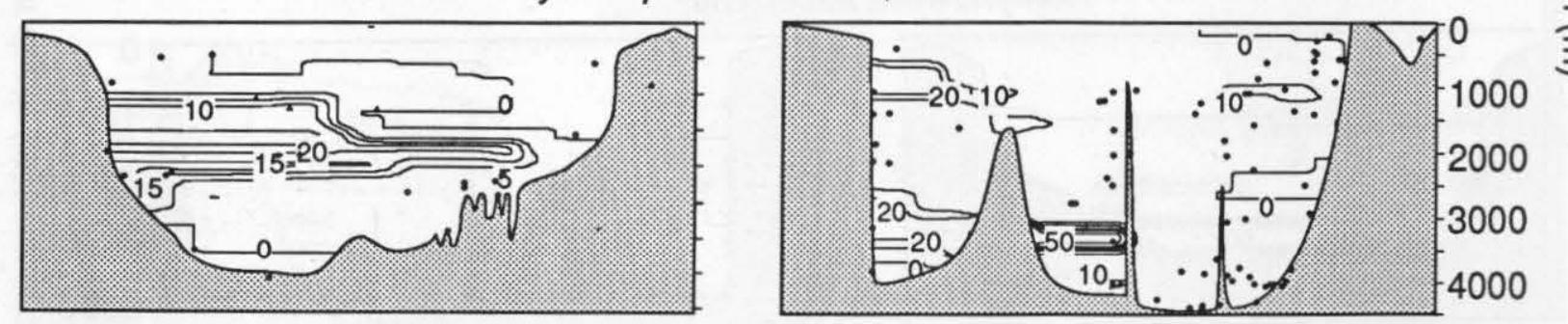

Cytheropteron hamatum
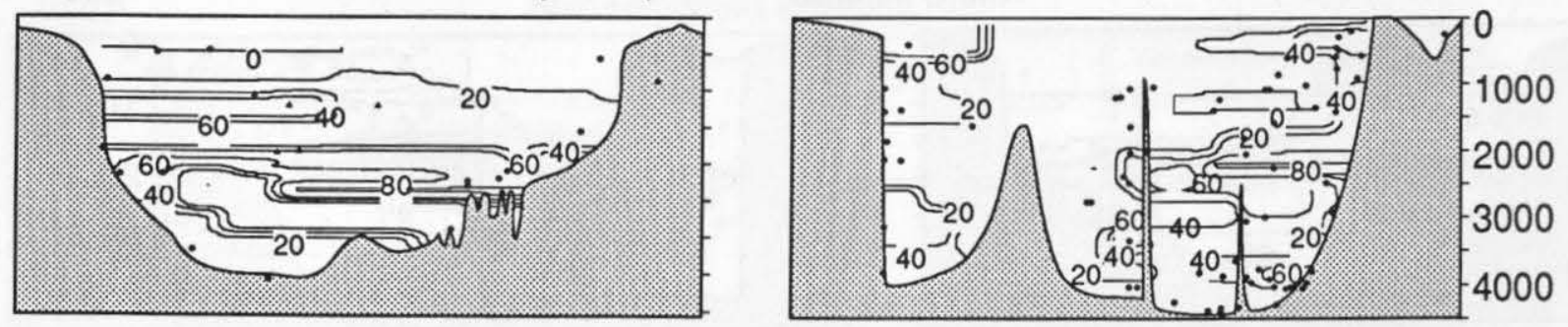

Krithe cf. pernoides

Figure 5. Contour plots of percentage of occurrences of Cytheropteron alatum, C. carolinae, C. hamatum, and Krithe cf. pernoides in the Fram Strait region and the Arctic Ocean. Black dots show core top stations; diamonds are northern Fram Strait region stations.

slope at depths $1100-2000 \mathrm{~m}$ (Figure 5). Its distribution coincides with Canada Basin water which flows across the Lomonosov Ridge and Morris Jesup Rise forming a core of relatively warm, saline Arctic Ocean outflow entering the Greenland Sea in the western Fram Strait. C. hamatum also inhabits intermediate depths between about $500-1500 \mathrm{~m}$ in the boundary current layer of the Laptev Sea (T.M. Cronin, unpublished data, 1994). High percentages of $C$. hamatum in downcore assemblages from the Lomonosov Ridge therefore suggest increased strength of boundary currents and Canada Basin water following Termination 1.

\section{Late Quaternary Paleoceanography}

Arctic glacial/interglacial sedimentation. Sedimentological changes occur in the Arctic during glacialinterglacial climatic transitions that have significance for interpreting ocean and sea-ice history. In general, turbidites characterize sedimentation in the deep Arctic Basins, whereas on ridges and plateaus, biogenic sediments predominate during interglacial periods and ice-rafted debris (IRD) during glacial periods [Fütterer, 1992; Phillips, 1994]. The late Quaternary record of the Northwind Ridge in the Canada Basin [Poore et 
ARCTIC OCEAN

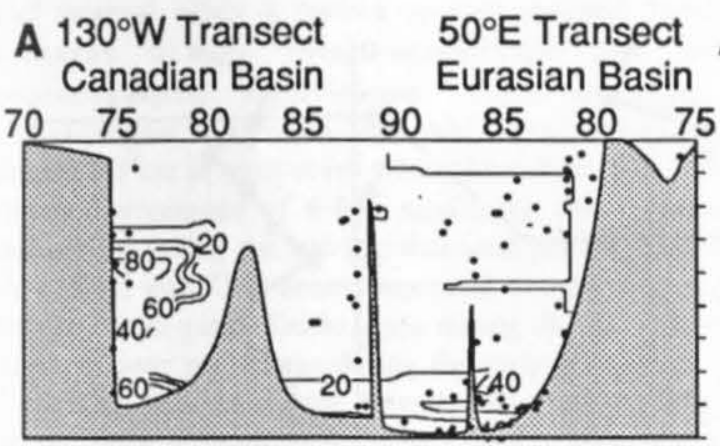

Cytheropteron bronwynae

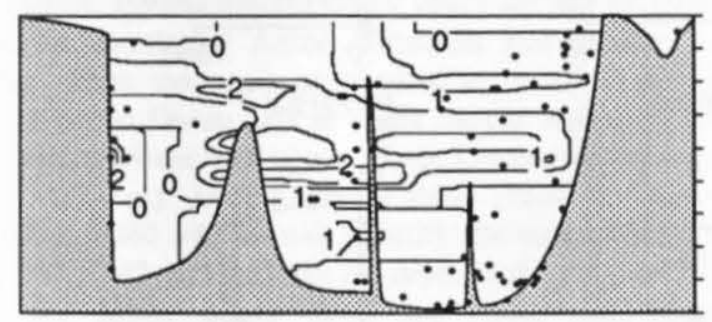

Pedicythere neofluitans

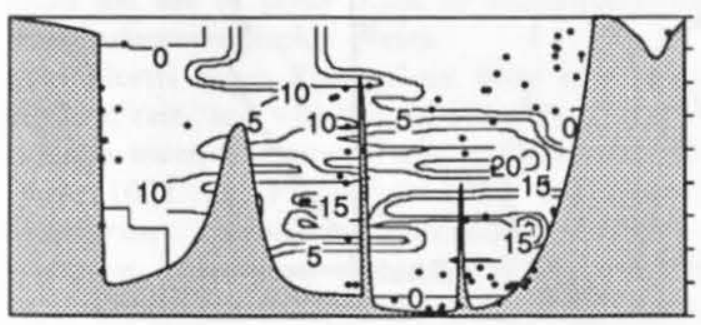

Acetabulastoma arcticum
ARCTIC OCEAN

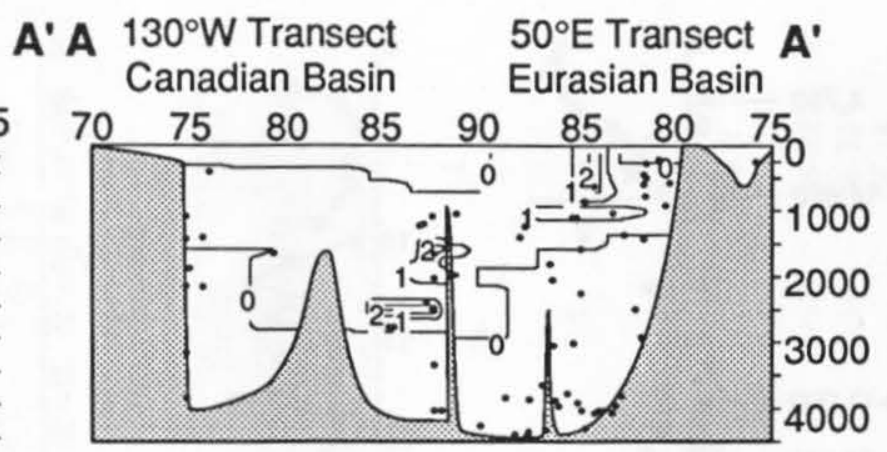

Bythoceratina scaberrima

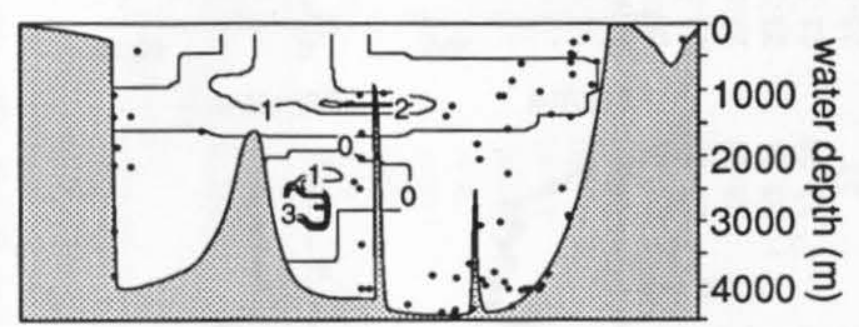

Microcythere medistriatum

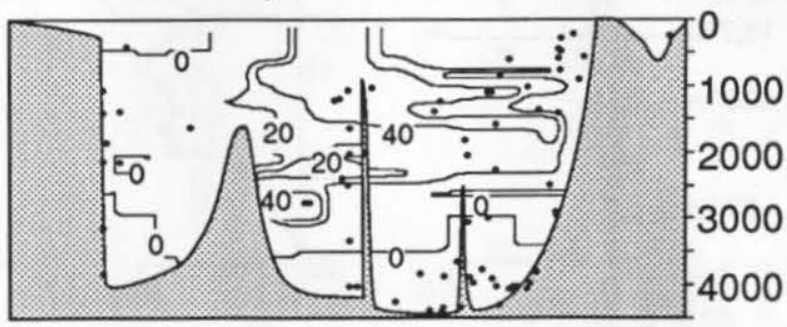

Polycope spp.

Figure 6. Contour plots of percentage of occurrences of Cytheropteron bronwynae, Bythoceratina scaberrima, Pedicythere neofluitans, Microcythere medistriatum, Acetabulastoma arcticum, and Polycope spp. in the Arctic Ocean. Black dots show core top stations; diamonds are northern Fram Strait region stations.

al., 1993], and the Lomonosov and Gakkel Ridges in the central and Eurasian Arctic [Stein et al., 1993] are characterized by alternations of microfossil-rich and microfossil-poor sediments representing interglacial and glacial periods respectively. These cycles may represent 100 kyr eccentricity cycles, although additional chronostratigraphic work is required for some sites. North of the Fram Strait, on the Morris Jesup Rise and Yermak Plateau in the eastern Arctic [Stein et al., 1993; C. Vogt et al., manuscript in preparation, 1995], glacial periods also have enhanced terriginous input via IRD; interglacial have lower terriginous input, higher amounts of biogenic sediment consisting of planktonic foraminifers, coccoliths and ostracodes. Calcareous nannofossils [Gard, 1988; Gard and Backman, 1990], high ${ }^{230} \mathrm{Th}$ and ${ }^{10} \mathrm{Be}$ values [Eisenhauer et al., 1994], ostracode faunal data [Cronin et al., 1994], and sedimentologic evidence [C. Vogt et al., manuscript in preparation, 1995] indicate higher sea-surface biologic productivity during the interglacial parts of $100-\mathrm{kyr}$ climatic cycles in this region. Thus, it is generally clear that over longer time periods, the relative abundance of planktonic and benthic calcareous microfossils in the central Arctic Ocean and along some Arctic margins decreased during glacial periods due to influx of ice-rafted siliciclastic material, decreased biologic productivity, and other factors [Stein et al., 1993, 1994b, c].

The Arctic record of the last glacial-deglacial cycle reflects a similar pattern. Typically, the uppermost $5-15 \mathrm{~cm}$ of the Polarstern multicores consists of sediment that is a brown clay with rare calcareous nannofossils and a coarse fraction consisting of planktonic and benthic foraminifers, ostracodes, sponge spicules, and other biogenic material [Fütterer, 1992; Stein et al., 1993]. Ostracodes were common in these intervals, reaching 400 to 1000 individuals $/ 30 \mathrm{~g}$ on the Lomonosov Ridge and $80-250$ individuals $/ 30 \mathrm{~g}$ in the deep Amundsen and Makarov Basins (Figure 7). Preservation in the upper $5-15 \mathrm{~cm}$ is usually excellent, valves range from translucent to opaque white; fragile juvenile specimens are common and well-preserved. 


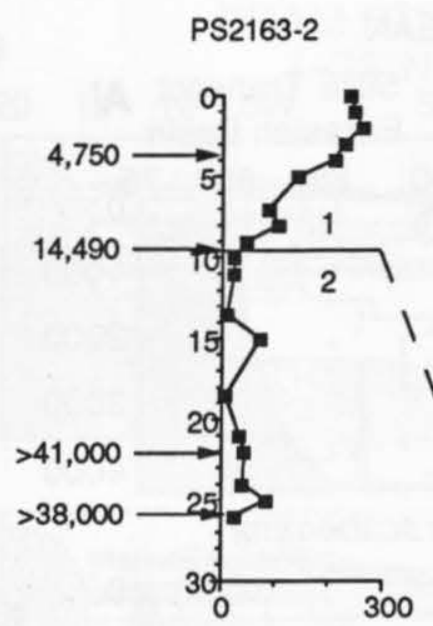

PS2179-3

PS2178-4

PS2202-4

PS2170-4

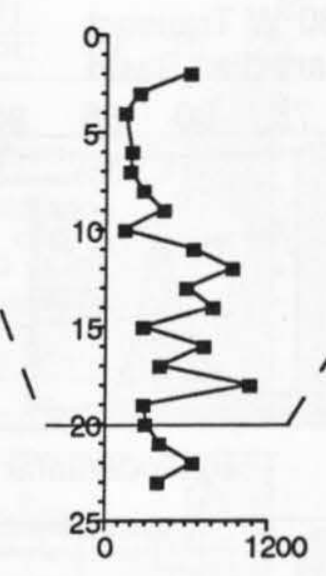

PS2185-4
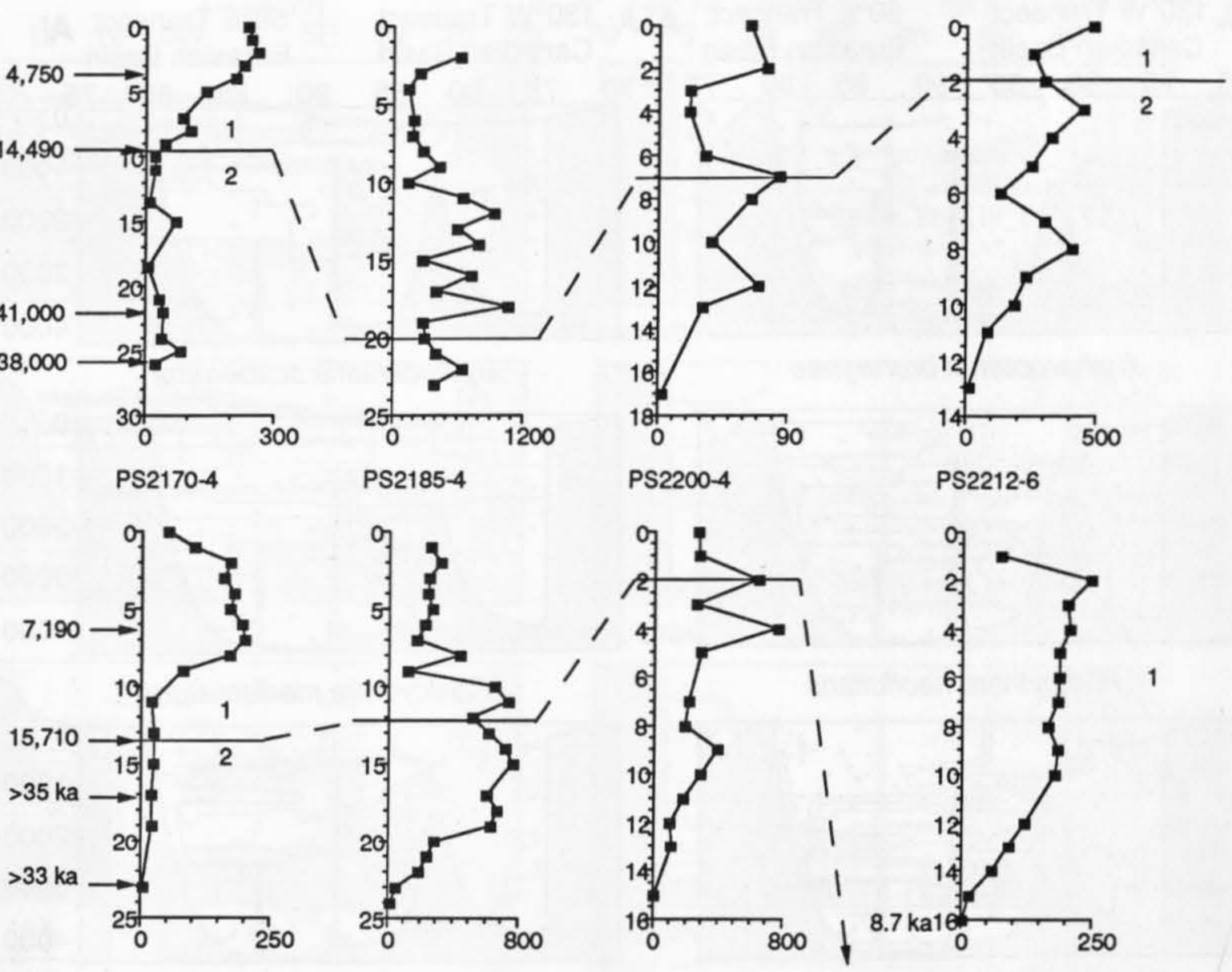

Figure 7. Plot of ostracode abundance (number of individuals per 30-g sample) for eight Arctic Ocean cores. Oxygen isotope stage $2 / 1$ boundary from Stein et al. [1994a] (alternative placement of the boundary in core PS2185-4 shown by dashed line). See Table 3 for summary of zones and text for discussion.

Below the biogenic-rich sediment, one usually finds $20-30$ $\mathrm{cm}$ of olive-grey clay or silty clay with no calcareous nannofossils [Gard, 1993] and minor amounts of other biogenic material. Sediment is dominated by siliciclastic material most likely transported as IRD. Ostracodes are usually absent to rare in the lowermost $10-20 \mathrm{~cm}$ of the multicores $(\approx 20-40 \mathrm{~cm}$ core depth) and increase in abundance up core. This increase is usually rapid occurring over only a 1$2 \mathrm{~cm}$ interval in central Arctic cores from the Lomonosov and Gakkel Ridges (i.e., Figure 7, PS2185-4). The first taxa to appear in the transition from siliciclastic to biogenic sediment at middepths on the Arctic ridges (Lomonosov Ridge cores PS2179-3 and PS2185-4; Gakkel Ridge core PS21632, PS2206) are Krithe, Henryhowella, and Eucythere. We interpret these assemblages as representing the end of glacial isotope stage 2 because these taxa are characteristic of modern cold, low nutrient habitats such as the Greenland Sea at depths below $2500 \mathrm{~m}$, not the modern environments at these sites on Arctic ridges. This interpretation is supported by the AMS dates of 14,490 yearrs B.P. and 15,710 years B.P. for glacialage sediments from cores PS2163 and PS2170 [Stein et al., 1994b, Figure 7] and isotope stratigraphy for all cores [Stein et al., 1994a].

Because late glacial assemblages occur in relatively low numbers in some cores, paleoceanographic inferences based on them require caution. It is possible that at some times during the last glacial, certain areas of the Arctic had minimal biotic activity, as suggested by Jones et al. [1994]. Nonetheless, the presence of Krithe, Henryhowella, and Eucythere and the absence of typical intermediate depth taxa in cores from various ridges and plateaus indicate that benthic faunas and environments were unlike modern interglacial assemblages from these depths (see discussion).

Ostracode faunal zones. Table 3 lists the 15 ostracode zones shown stratigraphically in Figure 8. Each ostracode zone is based on the percentages of key species in multicores PS2185-4 and PS2179-3, calculated from the species census data in Table A3 on microfiche and plotted in Figures 9-12. The proportions of indicator species in five box cores from either side of the Lomonosov Ridge are also plotted (Figure 13, box cores PS2185-3 and PS2179-1 are the same sites as the multicores in Figure 9a and 9b), showing the position of 
nine zones. Each zone is an informal acme zone, representing a brief interval when a certain species reached maximum percentages in the total assemblage and having paleoceanographic significance. For example, the Acetabulastoma Maximum (the AM zone) represents the uppermost 2-3 cm in most cores where Acetabulastoma reaches maximum percentages of $6-8 \%$, signifying the evolution of surface sea-ice during the last few thousand years. The Krithe maxima (KM1 and KM2 zones) represent two distinct peaks in abundance of the genus Krithe, one during the last glacial and the other, a lower percentage during the early Holocene.

These data demonstrate the reproducibility of the ostracode faunal sequence in replicate cores and over a wide area in the central Arctic in the depth range of $1000-2000 \mathrm{~m}$. There are, nonetheless, several qualifications about the use of ostracode zones for correlating Arctic sediments and inferring ocean history. First, the zones are limited to faunal events in the Central Arctic Ocean and at water depths within the Arctic Intermediate Water and upper Arctic Ocean deepwater layers $(1000-2000 \mathrm{~m})$. On the Gakkel Ridge (Table 3; Figure 11a; PS2163-1, $3040 \mathrm{~m}$ ), we can identify the major zones KM1, $\mathrm{HM}, \mathrm{PM}, \mathrm{KM} 2$, and AM, but the depth of this core $(3000 \mathrm{~m})$ is near the lower depth limit for using this zonation. Sedimentation rates of $1-2 \mathrm{~cm} / 1000 \mathrm{yr}$ and limited AMS dates also limits the use of these zones to millennial-scale late Quaternary paleoceanographic events.

On the Morris Jesup Rise, where there is a lower net sedimentation rate, and which is in the path of outflowing Canada Basin water, two cores (Table 3; Figure 10a and 10b; PS2200-4, $1072 \mathrm{~m}$; PS2202-4, $1083 \mathrm{~m}$ ) record the Cytheropteron carolinae maximum (CCM1), the Cytheropteron bronwynae maximum (CBM1), KM1, the Atlantic taxa maximum (ATLM), the PM and AM zones. On the Yermak Plateau, only the KM2, CCM2, the Cytheropteron alatum maximum (CAM), and AM zones can be found due to the high sedimentation rate. Faunal sequences that characterize the deep Makarov and Amundsen Basins in the lower Arctic Ocean deep water are quite distinct from those on the ridges (Figure 8 right side; see below) and will require a separate zonation for deep basins near $4000 \mathrm{~m}$ once additional cores have been studied.

Despite these limitations, these zones are useful for correlating late Quaternary sediments from the central Arctic Ocean from intermediate depth environments on ridges and plateaus. Furthermore, these late Quaternary ostracode faunal changes (indeed, there is essentially complete faunal turnover from the last glacial through Termination 1 at all water depths) indicate major oceanographic change during the last 16,000 years. This inference is substantiated by the relationship between faunal and stable isotopic patterns, shown for four cores in Figure 14. For example, relatively high proportions of $K$ rithe in intermediate depth cores (PS2185-3, PS2179-1, PS2163-2) are associated with high $\delta^{13} \mathrm{C}$ values; high proportions of Polycope correspond to low $\delta^{13} \mathrm{C}$ values. The Cytheropteron hamatum spike in PS2185-3 and PS2179-1 corresponds with the mid-Holocene rise in $\delta^{13} \mathrm{C}$. In the deep Amundsen Basin core PS2170-1, a rise in Krithe and a decrease in Cytheropteron corresponds with lighter $\delta^{18} \mathrm{O}$ values.

In order to quantitatively evaluate the meaning of these faunal changes, we carried out faunal analyses using the

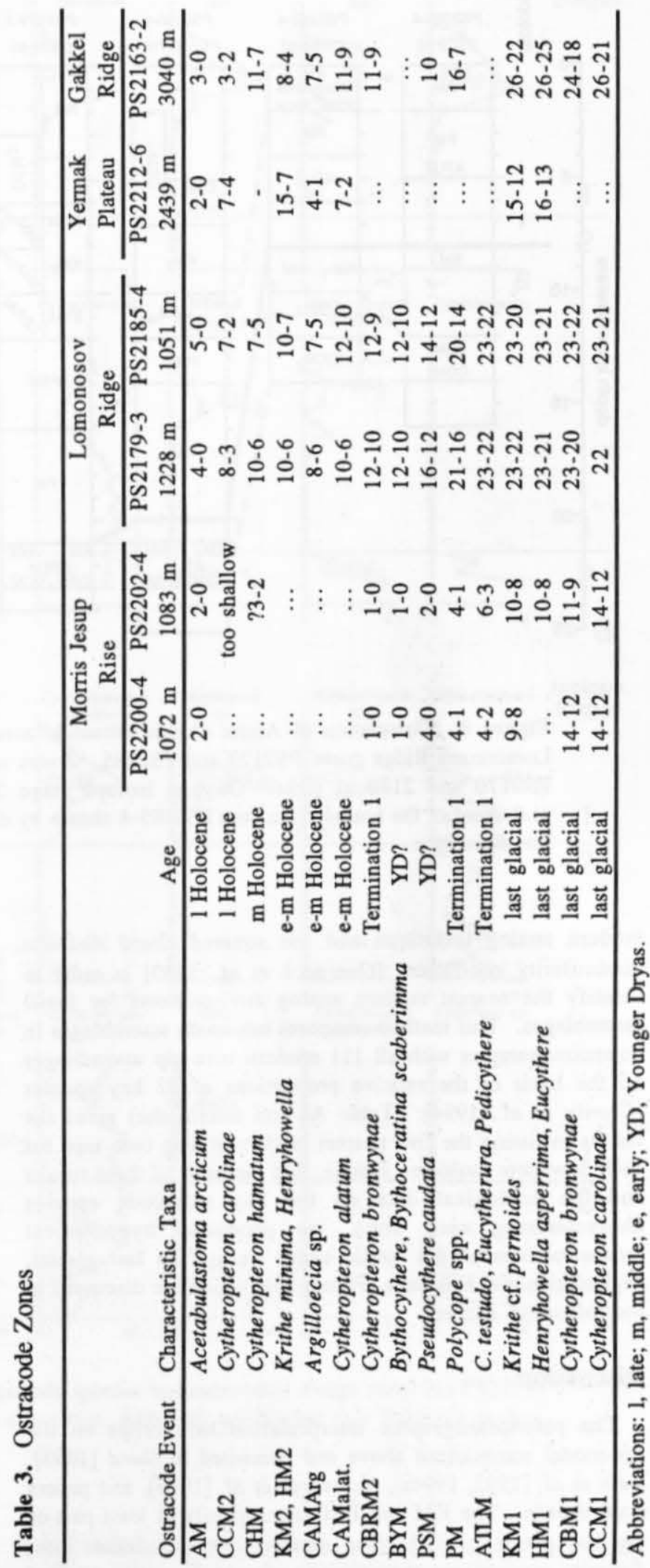




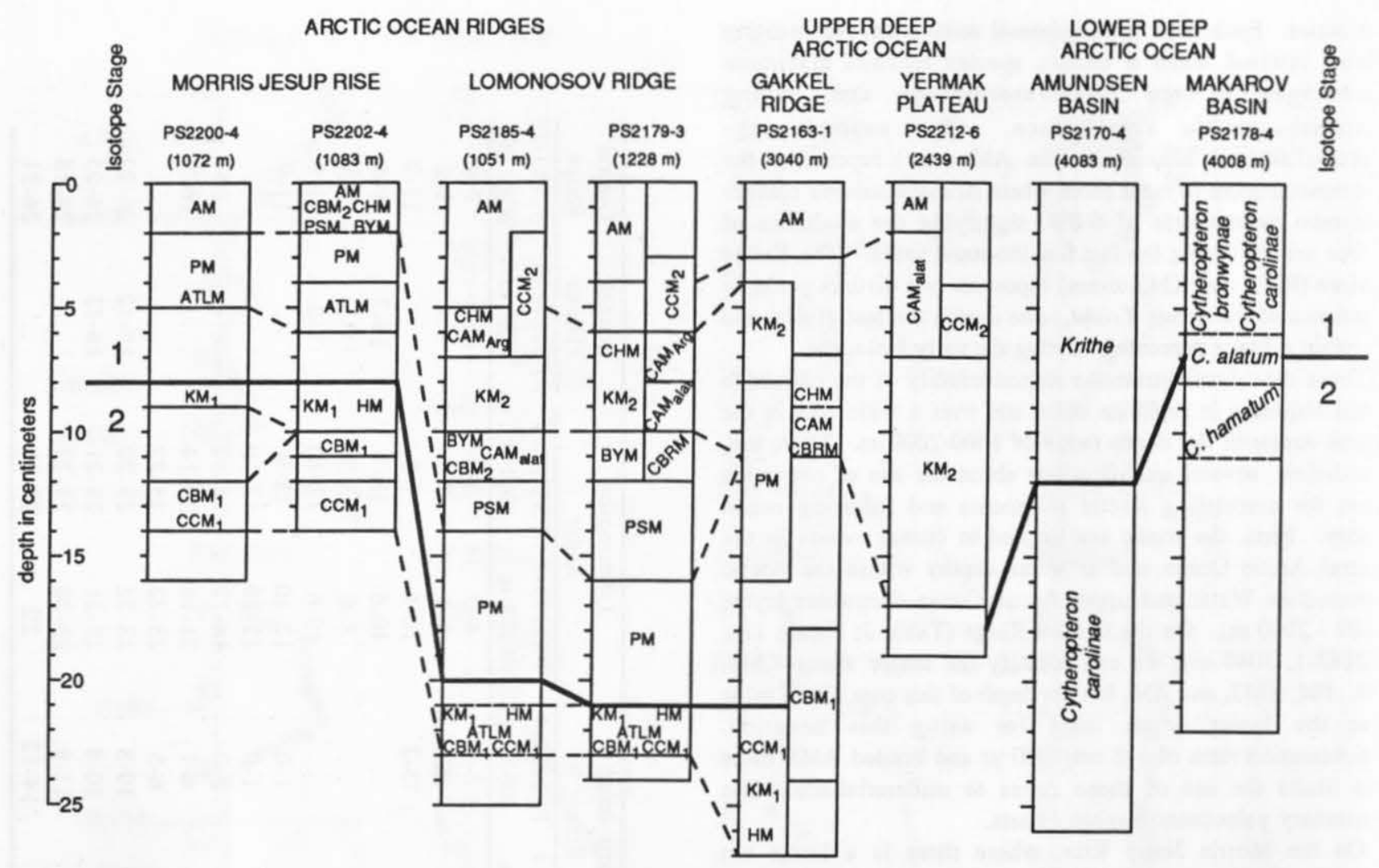

Figure 8. Correlation of Arctic Ocean ostracode zones AM-KM1. Complete sequence of zones occurs in Lomonosov Ridge cores PS2179 and PS2185. Zones are not applicable in deep Arctic basins shown in cores PS2170 and 2178 at right. Oxygen isotope stage 2/1 boundary from Stein et al. [1994a] (alternative placement of the boundary in core PS2185-4 shown by dashed line). See Table 3 for summary of zones and text for discussion.

modern analog technique and the squared chord distance dissimilarity coefficient [Overpeck et al., 1985] in order to identify the nearest modern analog environments for fossil assemblages. This method compares ostracode assemblages in downcore samples with all 111 modern core top assemblages on the basis of the relative proportions of 22 key species [Cronin et al., 1994]. Table A4 (on microfiche) gives the results in listing the five nearest modern analog core tops for each downcore multicore sample. On the basis of these results and the ecological data on the key ostracode species characterizing each zone, we produced hypothetical reconstructions of the Arctic ocean during the last glacial, deglaciation and Holocene (Figure 15) which are discussed in the following section.

\section{Discussion}

The paleoceanographic interpretation here relies on the age-model summarized above and presented in Gard [1993], Stein et al. [1993, 1994a], Nowaczyk et al. [1995], and papers cited therein. The KM and HM zones signify at least part of the last glacial period when distinct low-abundance, lowdiversity assemblages characteristic of cold, low nutrient deep water inhabited intermediate depths in the central Arctic. In apparent conflict with the interpretation of the age of the KM and HM zones, Jones et al. [1994] postulated that the central Arctic Ocean may have been abiotic during the period encompassing the last glacial, from about 30,000 to 13,000 years. While Arctic biogenic sediment production and surface productivity were reduced during glacials and perhaps absent in some regions, there is evidence for surface and benthic biotic activity in some regions. For example, the reservoir-corrected planktonic foraminiferal AMS dates of 14,490 year B.P. +/$140 \mathrm{yr}$, and 17,500 year B.P.+/-340 from the Gakkel Ridge and 15,710 year B.P. $+/-180$ from the Amundsen Basin [Stein et al., 1994b] indicate planktonic foraminifers lived near the time of the last glacial maximum. Moreover, isotope curves from the planktonic foraminifer $N$. pachyderma indicate that stages $2 / 1$ transition can be identified in many cores [Stein et al., 1994b], suggesting that some planktonic foraminifers occurred in prestage 1 glacial age material. At some sites (i.e., PS2178, PS2200, PS2202), ostracodes occur throughout the entire cored interval which most likely includes some glacialage material. Biotic productivity even during glacial periods might be expected in ice marginal areas such as the Morris Jesup Rise (PS2200, PS2202). In central Arctic cores, glacial age ostracodes are rare (i.e., PS2185-4, Figure 7), but if our interpretation of the Krithe/Henryhowella assemblage as a glacial assemblage is correct, then these assemblages represent at least the final part of the last glacial period. 
PS2179-3
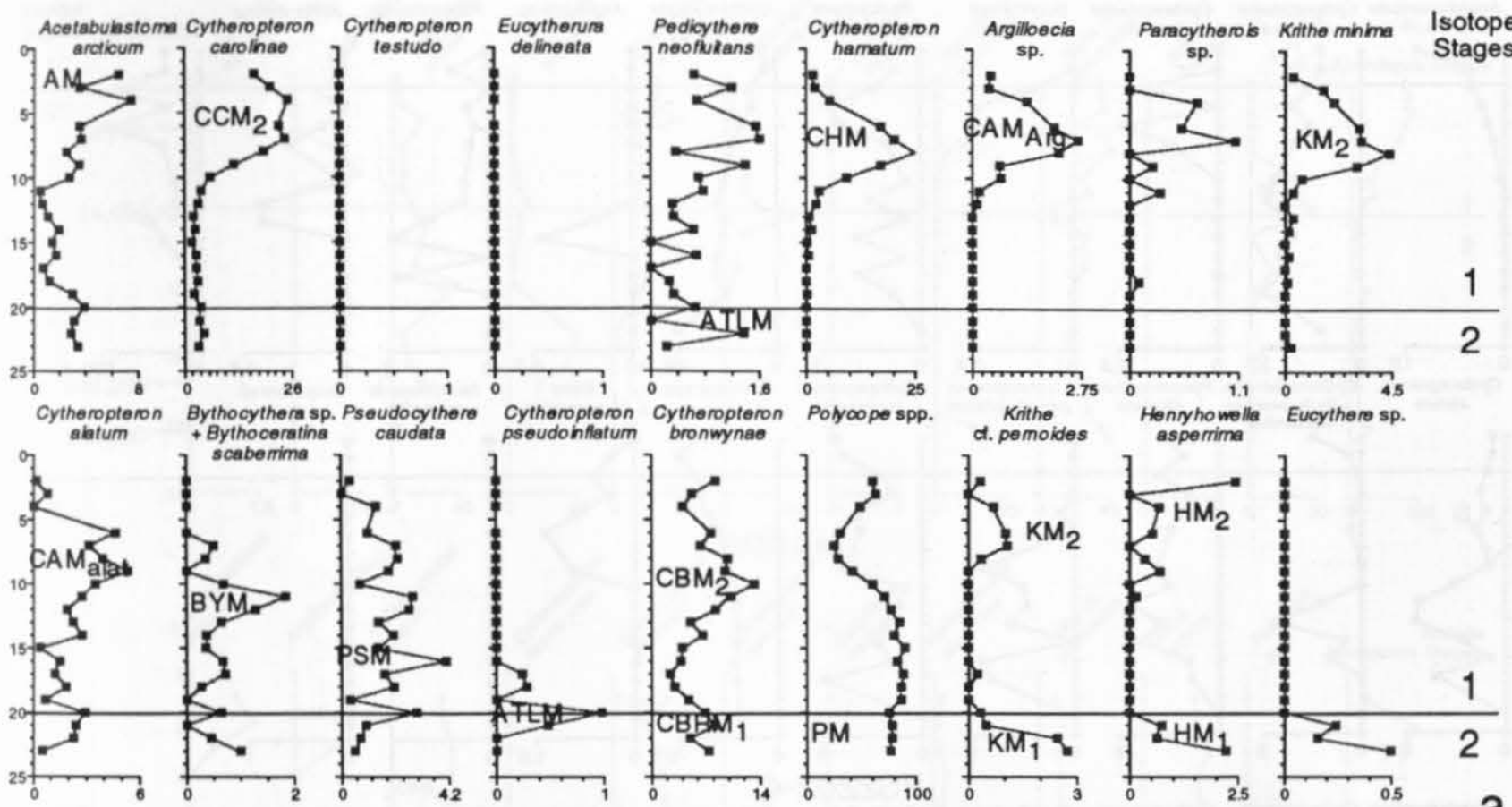

PS2185-4
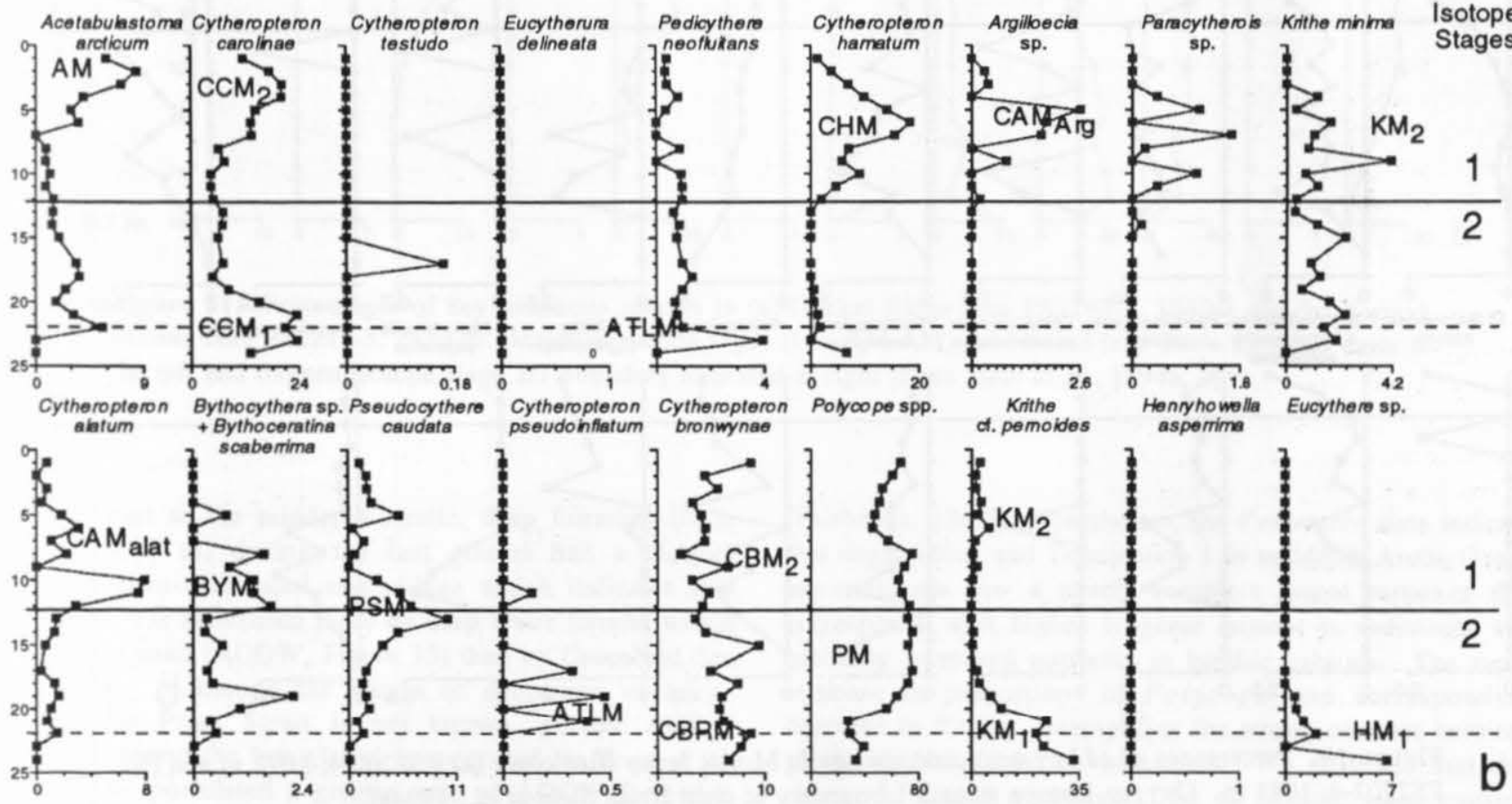

Figure 9. Plot of percentage of occurrence of key ostracode species in Lomonosov Ridge cores (a) PS21793, $1228 \mathrm{~m}$ and (b) PS2185-4, $1051 \mathrm{~m}$. Major ostracode zones (i.e., KM-AM) are labeled (see Table 3); oxygen isotope stage $2 / 1$ boundary indicated at right.

Taken together, the ostracodes and planktonic foraminfers indicate at least some benthic and planktonic organic activity in the central Arctic and in marginal regions of the Eurasian Basin during parts of the last glacial, but additional dating and paleoenvironmental study is needed to determine the spatial and temporal nature of Arctic glacial environments.

With this in mind, the KM and HM zones can be explained it during the last glacial, intermediate depth water $(\approx 1000$ - 


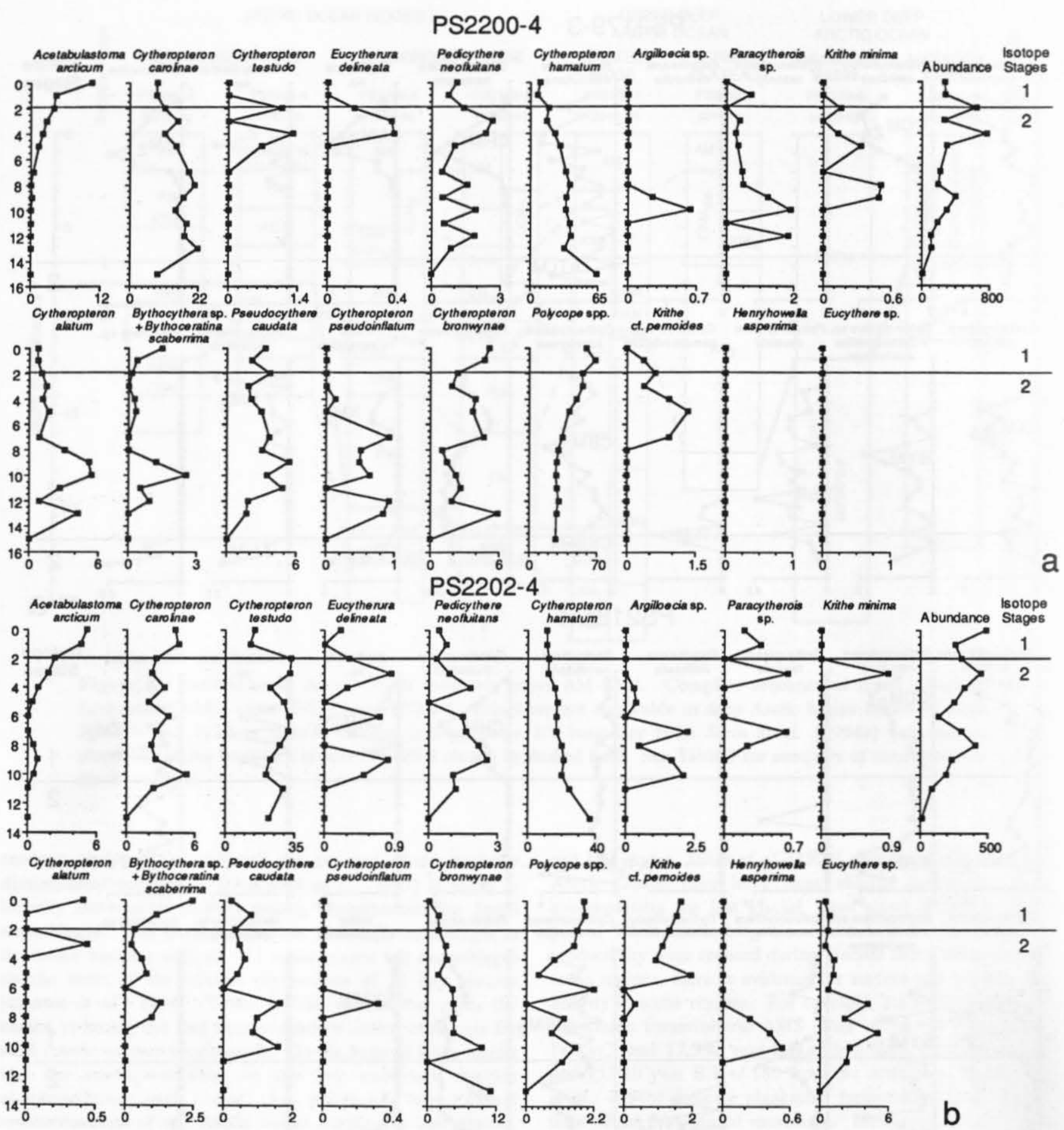

Figure 10. Percentages of of key ostracode species in Morris Jesup Rise cores (a) PS2200-4, $1072 \mathrm{~m}$ and (b) PS2202-4, $1083 \mathrm{~m}$. Oxygen isotope stage 2/1 boundary at right [from Stein et al., 1994a].

$2000 \mathrm{~m}$, perhaps as deep as $3000 \mathrm{~m}$ ) in the Central Arctic Ocean was cold, low salinity, and well oxygenated, similar to modern deep Greenland Sea Water, which is about $1^{\circ} \mathrm{C}$ colder than modern middepth central Arctic Ocean water (Figure 15, top). The absence or low abundance of Polycope and the dominance of Krithe also suggest that during the last glacial period AIW was relatively poor in nutrients. These interpretations support the hypothesis of Veum et al. [1992] that GSDW is at least partially responsible for nutrientdepleted intermediate waters in the Atlantic [Boyle and Keigwin, 1987; Boyle, 1988; Oppo and Fairbanks, 1987; Slowey and Curry, 1992]. The deep Greenland Sea analog for the glacial-age middepth central Arctic indicates an absence of warm, high-salinity Atlantic water in the Arctic at that time. 

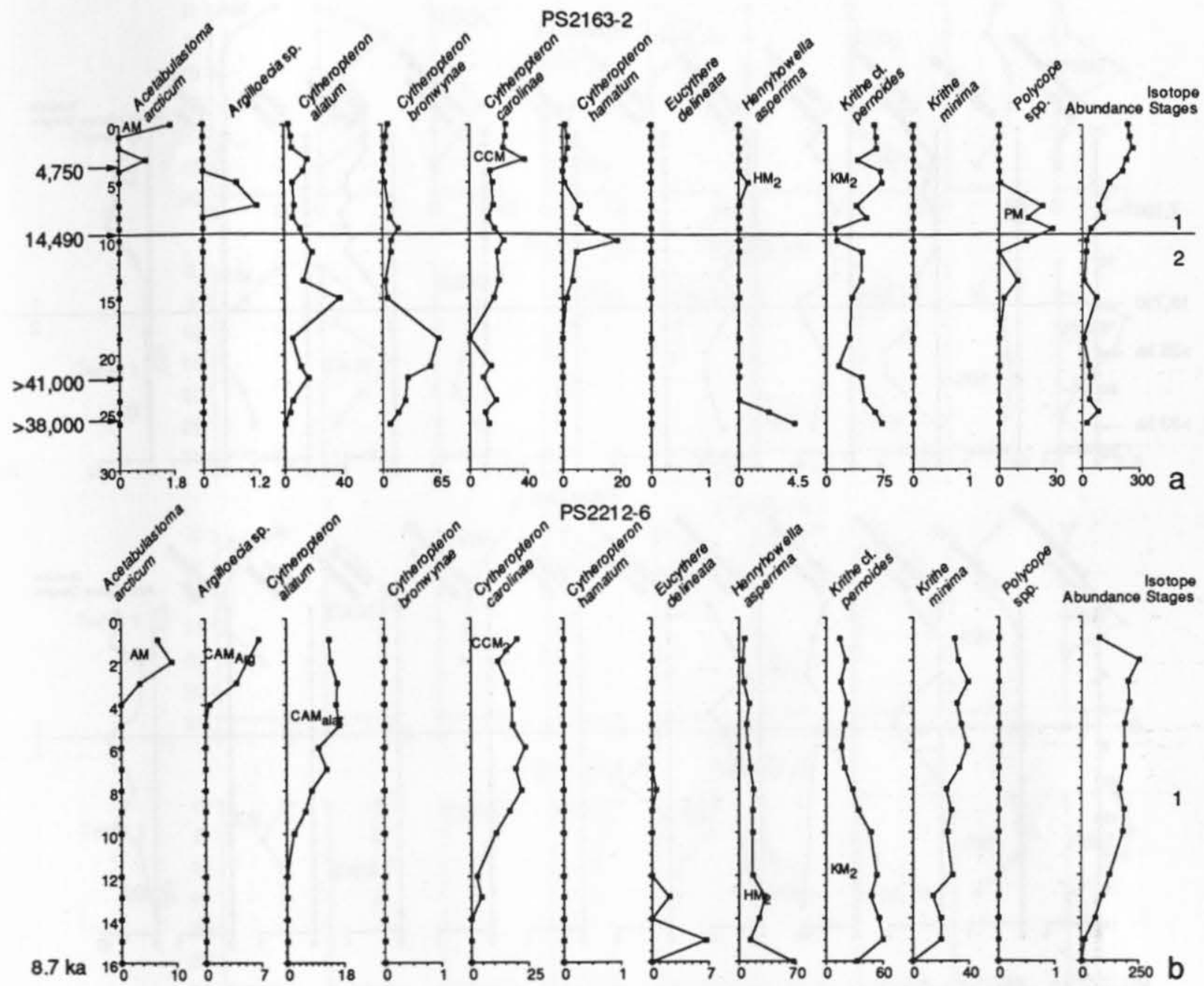

PS2212-6
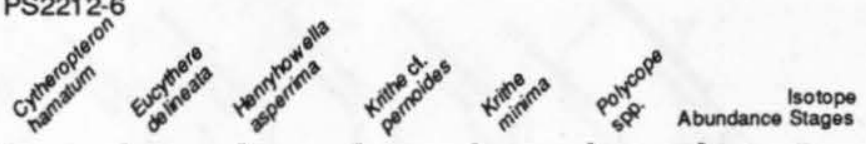

Figure 11. Percentages of key ostracode species in (a) Gakkel Ridge core PS2163-2, 3040m and (b) Yermak Plateau core PS2212-3, 2439 m. Major ostracode zones (i.e., KM-AM) are labeled (see Table 2); AMS dates to the left and oxygen isotope stage $2 / 1$ boundary indicated at right [from Stein et al., 1994a, b].

In contrast to the middepth Arctic, deep Eurasian Basin water $(>3000 \mathrm{~m})$ during the last glacial had a distinct Cytheropteron-dominated assemblage which indicates that this region was influenced more by deep water formed within the Arctic Ocean (AODW, Figure 15) than by Greenland Sea deep water. Although the nature of deepwater exchange through the Fram Strait is not known, greater AODW formation during the last glacial is supported by Veum et al. [1992], who postulated a greater ratio of AODW formation compared to GSDW formation for glacial periods based on studies of the late Quaternary isotope record of the Norwegian Sea.

Faunal changes in the Arctic during earliest deglaciation and Termination 1 were complex and their paleoceanographic significance is not yet completely understood. There is as yet no clear faunal signal coinciding with the strong meltwater spike recorded in the isotopic record from the eastern Arctic near 15,700 years B.P. [Stein et al., 1994a] that pre-dated the global ice volume events between $13,500-9,000$ years B.P.
[Fairbanks, 1989]. Nonetheless, the Polarstern data indicate that deglaciation and Termination 1 in middepth Arctic Ocean environments saw a nearly complete faunal turnover that corresponds with higher biogenic content in sediments and probably increased nutrients in benthic habitats. The rapid increase in proportions of Polycope and corresponding decrease in Krithe exemplifies the strong contrast between glacial and deglacial environments. We postulate that this change is due to a stronger flow of Atlantic water causing increased sea surface productivity and perhaps reduced sea ice, an interpretation consistent with data for warm water inflow from the West Spitzbergen Current [Lehman and Forman, 1992]. The proportions of Polycope during deglaciation were even greater than those today, which suggests inflowing North Atlantic water was stronger and perhaps sea-ice cover was less than it is in the modern central Arctic Ocean (Figures 9 and 14).

The two-step nature of deglaciation recognized in sea level [Fairbanks, 1989], oceanic records [Broecker et al., 1985], and 


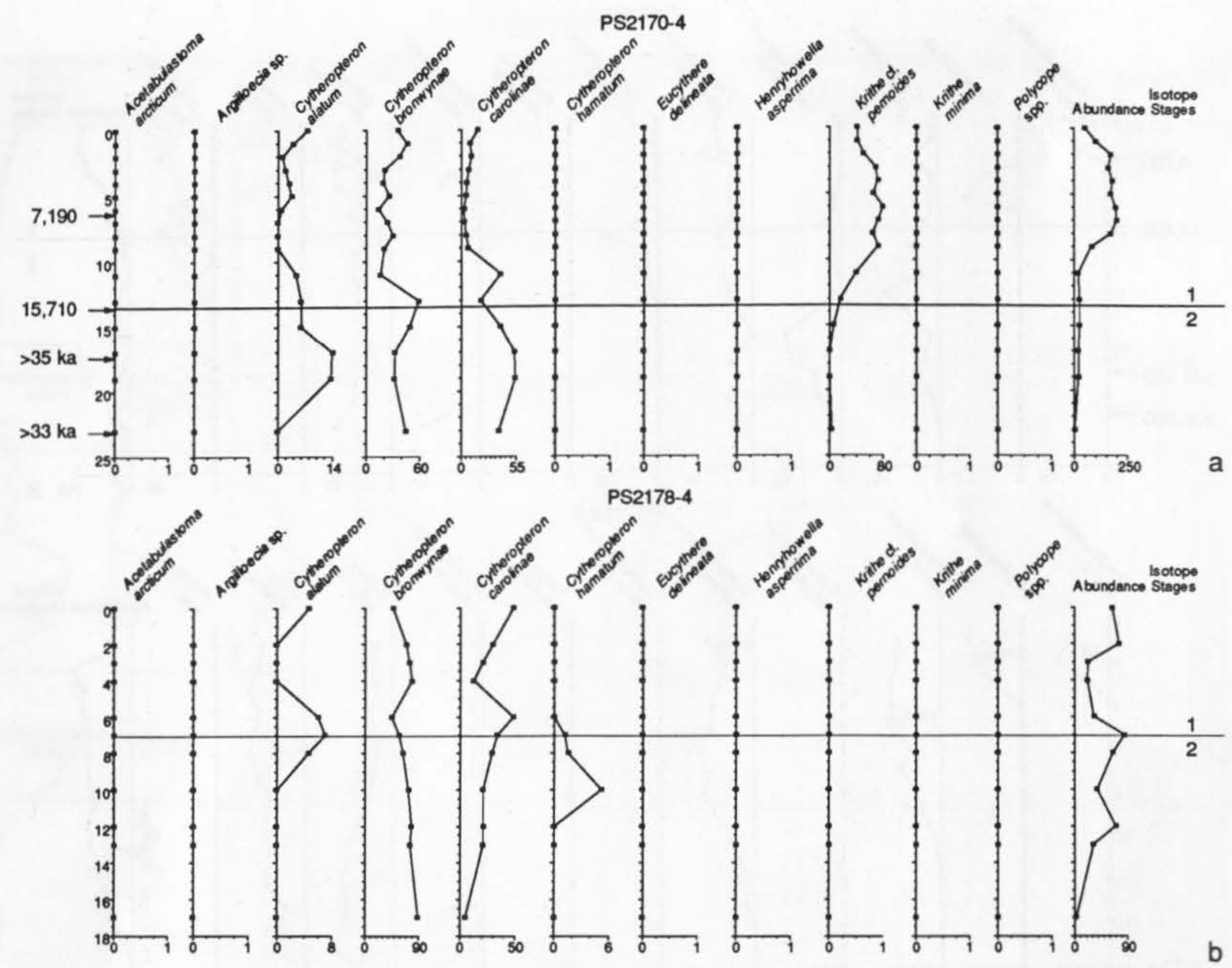

Figure 12. Plot of percentage of occurrence of key ostracode species in (a) Amundsen Basin core PS2170-4, $4083 \mathrm{~m}$ and (b) Makarov Basin core PS178-4, $4008 \mathrm{~m}$. Oxygen isotope stage 2/1 boundary indicated at right [from Stein et al., 1994a], AMS dates at left [from Stein et al., 1994b].

glacial and nearshore marine records [Lehman and Forman, 1992] is a problem in the Arctic Ocean because low sedimentation rates make the identification of this $800-1,000$ year event difficult. Nonetheless, there are clear faunal changes throughout the interval estimated to include Termination $1(\approx 13,500-9,000$ years B.P., ATLM, PM, PSM, BYM, CBRM2 zones, Table 3). In fact, the ostracode assemblages indicate that distinct oceanographic conditions characterized early and late phases of Termination 1. For example, in intermediate depth cores of the Lomonosov Ridge, faunas of early Termination 1 had greater proportions of North Atlantic species (including Pseudocythere caudata) than did those in the later part, which had more Canada Basin species (mainly Cytheropteron species). One explanation for these faunal changes may be the greater meltwater discharge and North Atlantic inflow during early Termination 1, which theoretically might lower salinities in the polar surface water, upset the halocline, and decrease brine formation [Aagaard and Carmack, 1989]. There is no faunal evidence during Termination 1 for a cessation of strong North Atlantic water influence in cores at $1000-1200 \mathrm{~m}$ water depth in the central Arctic nor evidence for greater GSDW influence at intermediate depths, such as occurred during the last glacial. The dominance of Polycope throughout Termination 1 (Figures 9 and 14) indicates continual influence of warm inflowing Atlantic water at middepths, as found by Jansen and Veum [1990] for the Norwegian Sea.

The Holocene record of the deep and intermediate depth Arctic shows that large faunal and oceanic changes occurred on a scale almost as great as those of the glacial-deglacial transition. The end of the deglaciation is marked by the abrupt faunal change when increases in Krithe, Henryhowella and $C$. alatum signify a brief period of weaker Atlantic water and stronger GS water at middepths in the Central Arctic (Figure 15). There is also a corresponding decrease in Polycope at this time. This period overlaps the Cytheropteron hamatum zone about 7000-6000 years B.P. this species reaches up to 20$25 \%$ in assemblages throughout a wide area in the Central Arctic Ocean, including the central Lomonosov Ridge (Figure 9 ) and possibly the Gakkel Ridge. The $C$. hamatum peak 

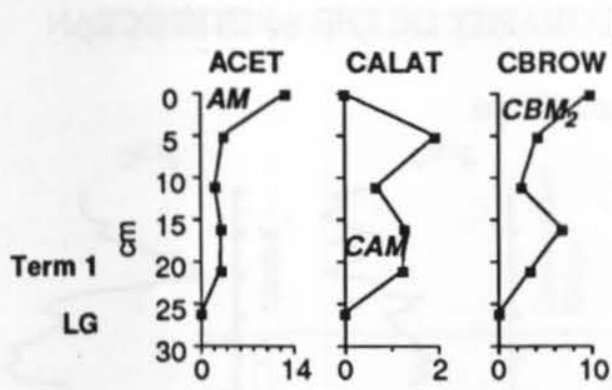

PS2185-3 $1051 \mathrm{~m}$
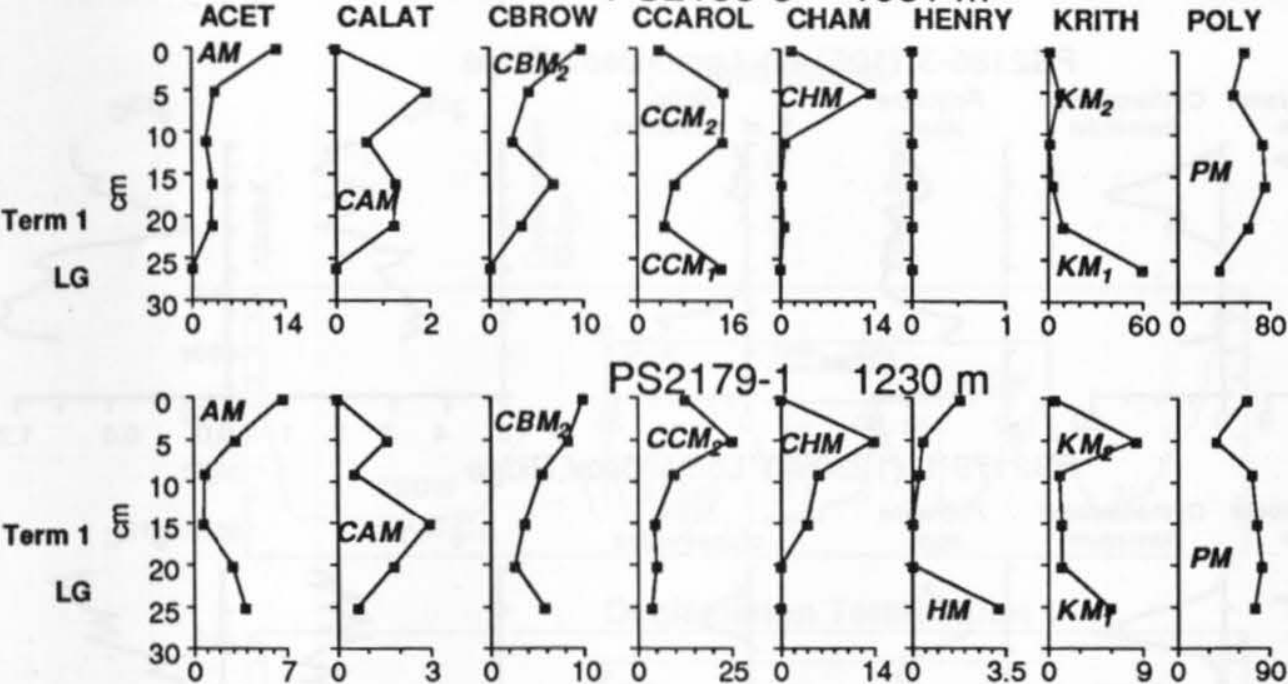

PSEUDO
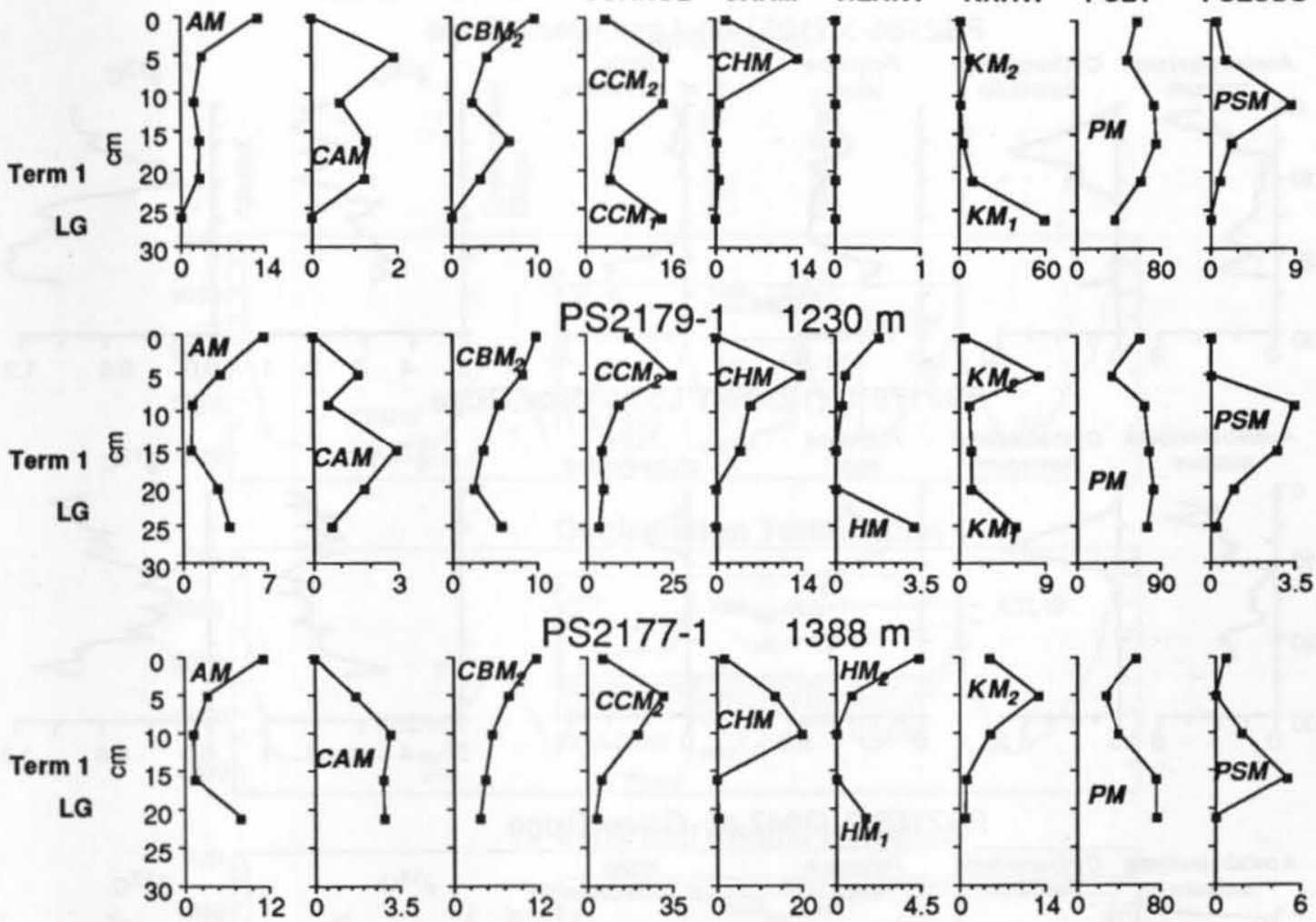

PS2177-1
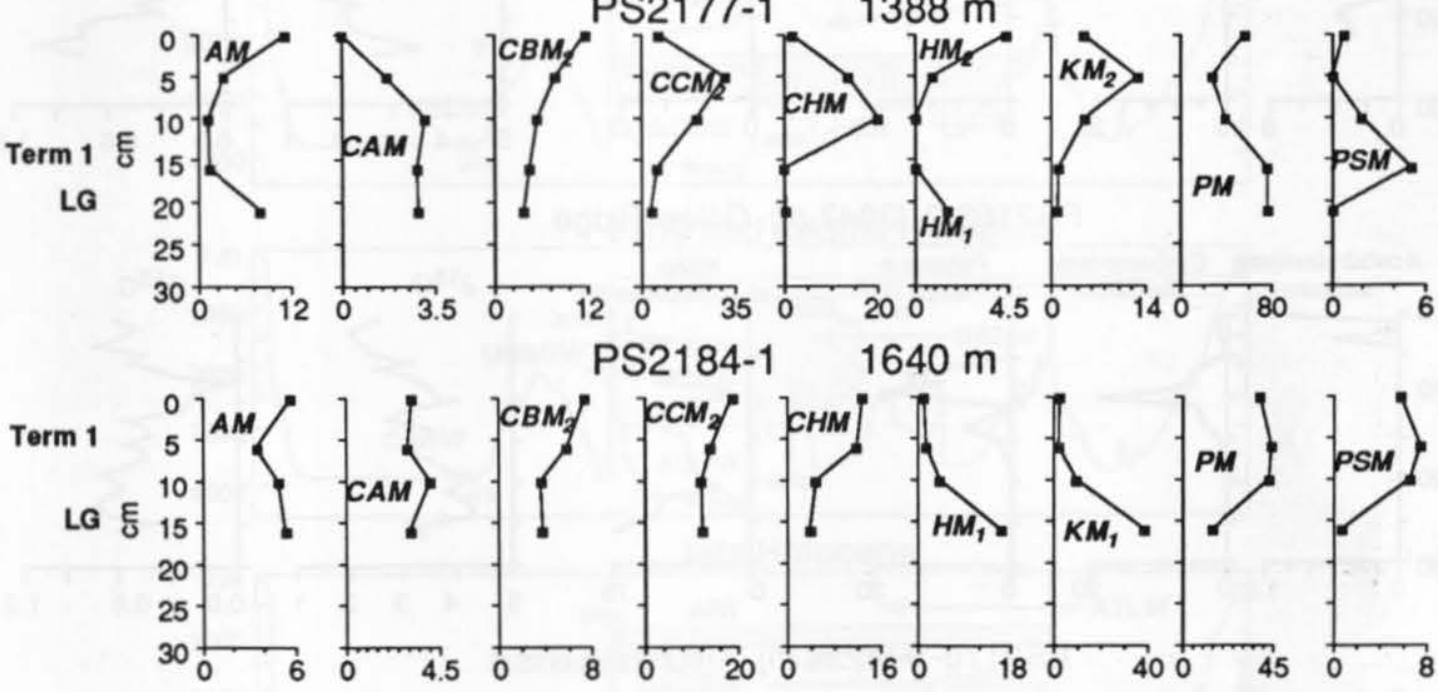

PS2184-1

$1640 \mathrm{~m}$
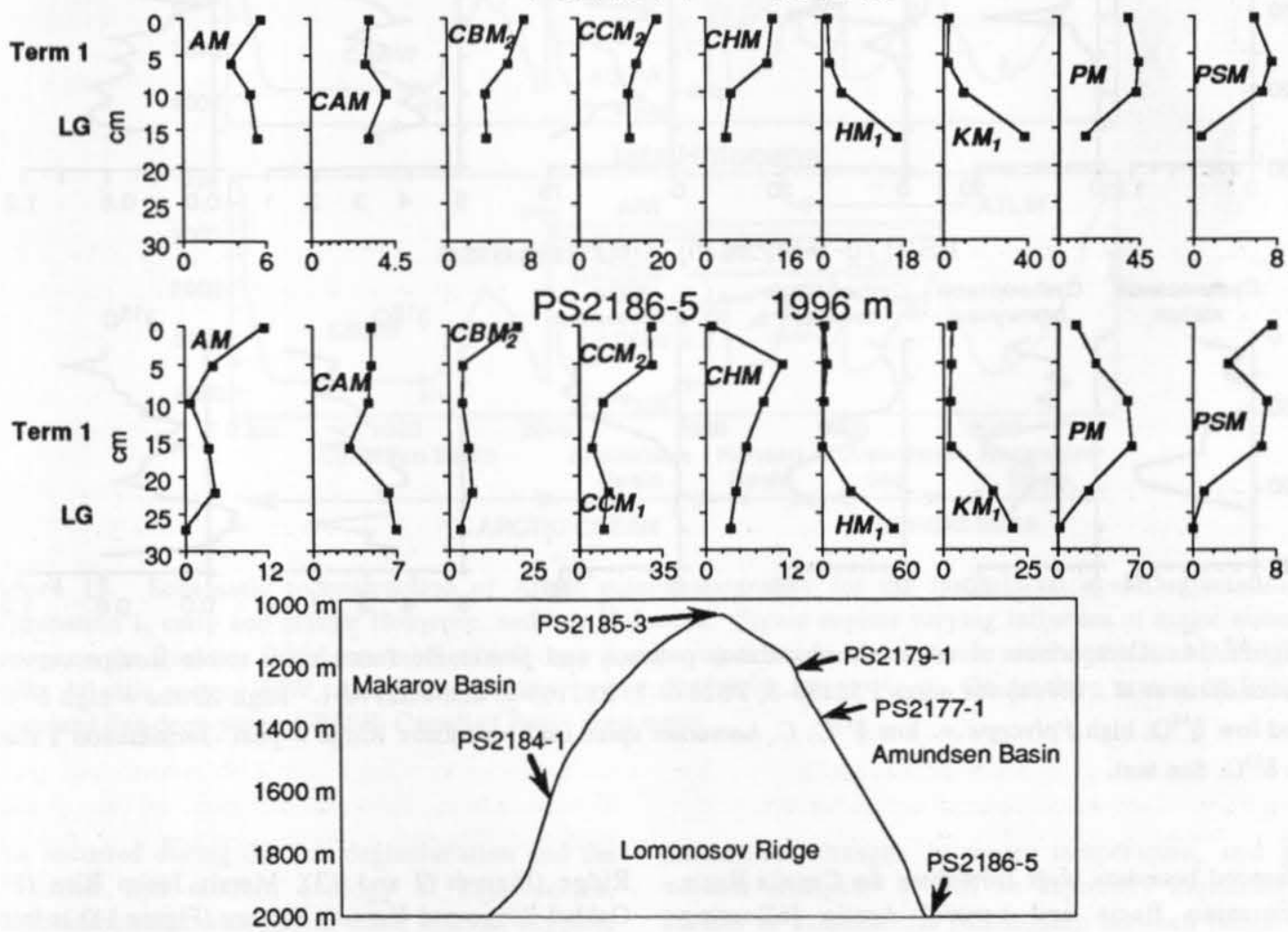

Figure 13. Plot of key ostracode species and location of major ostracode zones from 5 Lomonosov Ridge box cores; compare to multicores from same site, Figure 9 (modified from Cronin et al., [1994]). Term 1, Termination 1; LG, last glacial. Below, schematic cross-section on core bathymetries. Species abbreviations: Aceta, Acetabulastoma arcticum; Calat, Cytheropteron alatum; Cbrow, Cytheropteron bronwynae; Ccarol, Cytheropteron carolinae; Cham, Cytheropteron hamatum; Henry, Henryhowella asperrima; Krith, Krithe spp., Poly, Polycope spp., Pseudo, Pseudocythere caudata. 

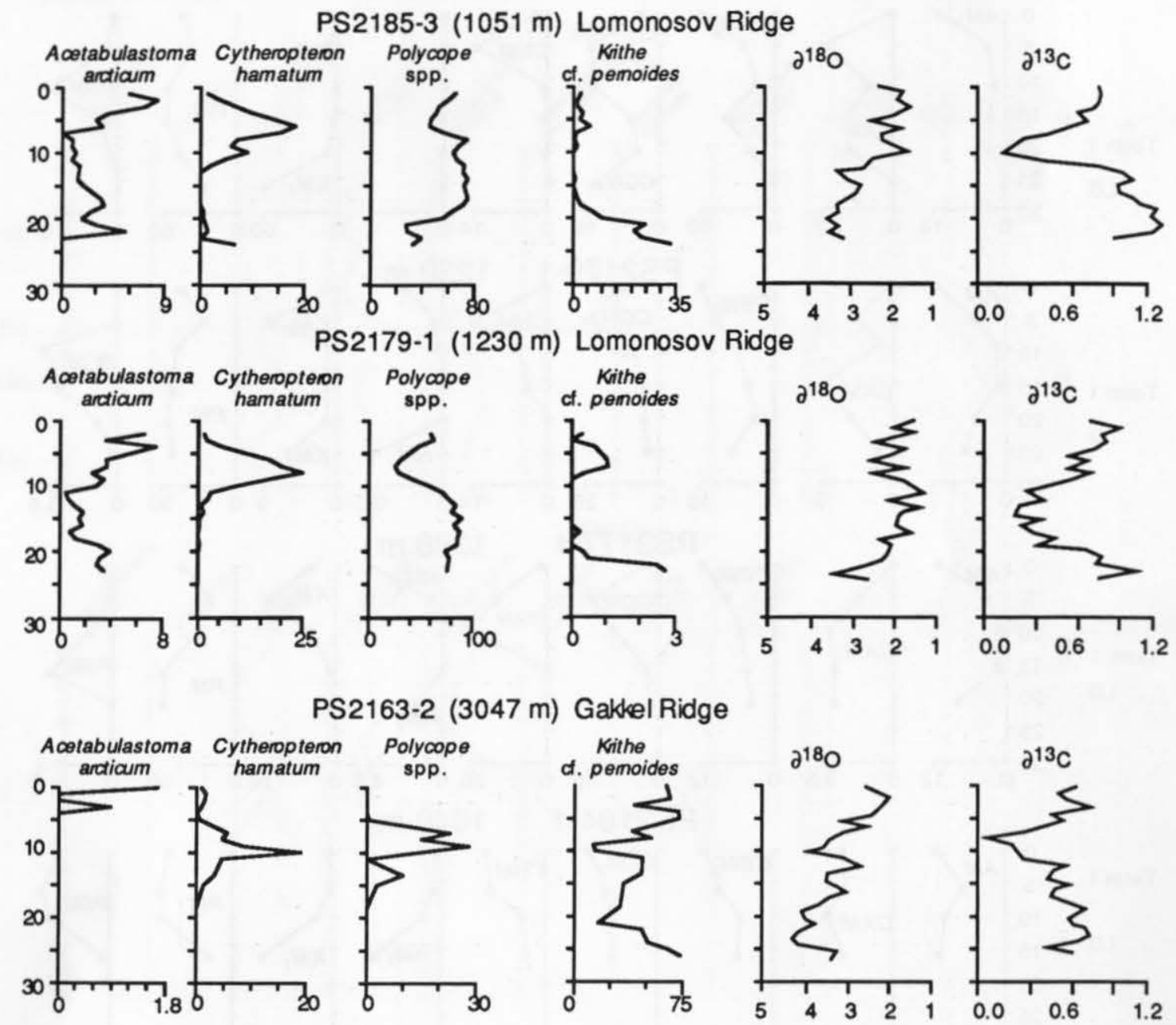

PS2163-2 (3047 m) Gakkel Ridge
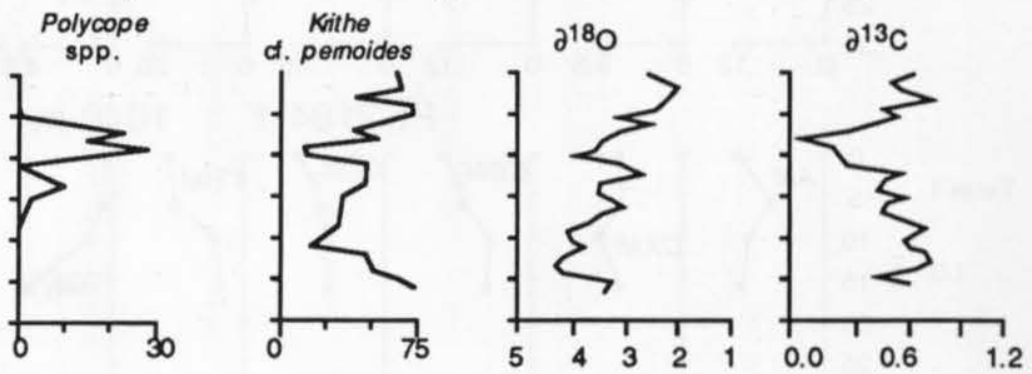

PS2170-1 (4226 m) Amundsen Basin
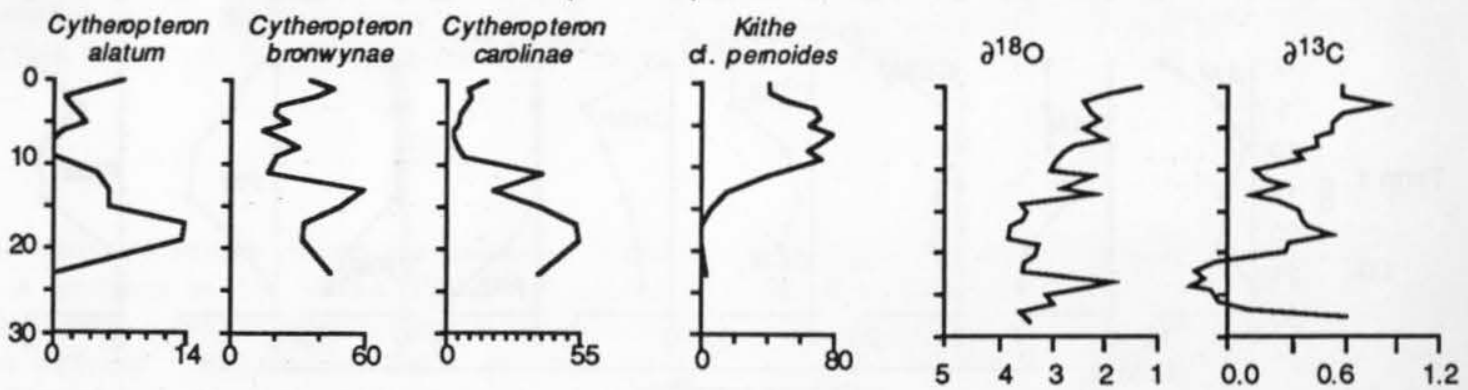

Figure 14. Comparison of ostracode abundance patterns and planktonic foraminifer stable isotope curves [from Stein et al., 1994a] for cores PS2185-3, PS2179-1, PS2163-2, and PS2170-1. High Krithe $=$ high $\delta^{13} \mathrm{C}$ and low $\delta^{18} \mathrm{O}$; high Polycope $=$ low $\delta^{13} \mathrm{C} ; \mathrm{C}$. hamatum spike on Lomonosov Ridge $=$ post - Termination 1 rise in $\delta^{13} \mathrm{C}$. See text.

suggests enhanced boundary layer flow from the Canada Basin into the Eurasian Basin and central Arctic following Termination 1.

The modern depth-stratified benthic assemblage structure of the modern Arctic evolved during the last few thousand years. The most notable oceanographic indicator for this period is Acetabulastoma arcticum, whose widespread increase in the uppermost 5-8 centimeters of cores from the Lomonosov
Ridge (Figures 9 and 13), Morris Jesup Rise (Figure 10), Gakkel Ridge and Yermak Plateau (Figure 11) is interpreted to signify the evolution of extensive perennial sea ice during the last 4000-5000 years.

In conclusion, although we are only beginning to understand the late Quaternary oceanographic history of the Arctic Ocean, the faunal data presented above provide convincing evidence that complex changes in Arctic benthic 


\section{last glacial}
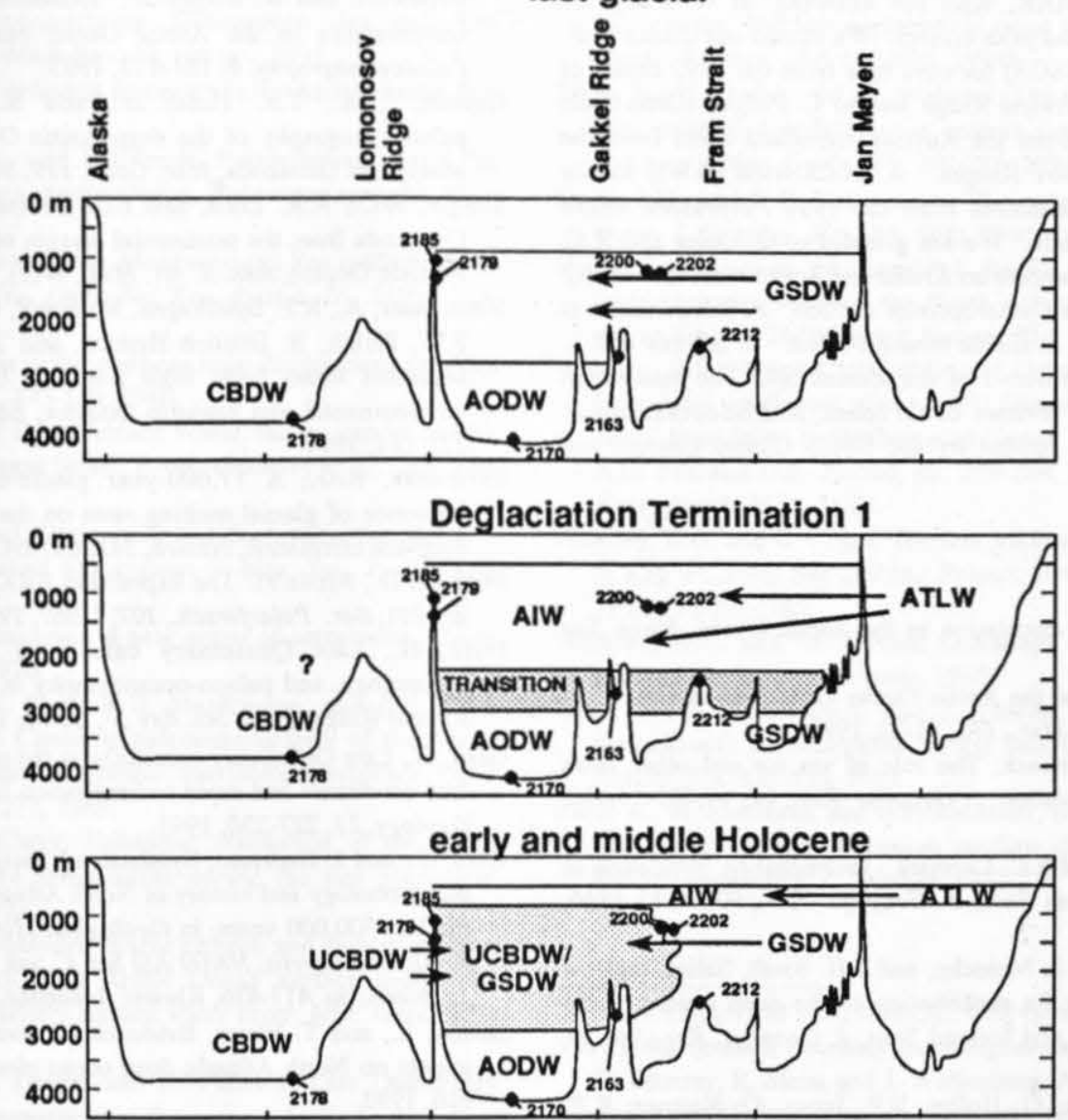

late Holocene

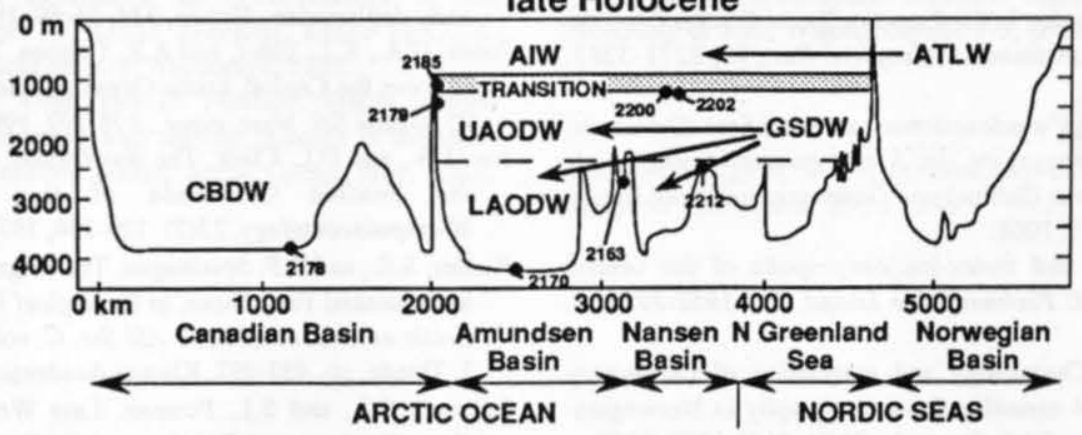

Figure 15. Schematic reconstruction of Arctic paleoceanography for the last glacial age, Deglaciation Termination 1, early and middle Holocene, and late Holocene. Figure depicts varying influence of major water masses on the Eurasian Basin intermediate and deep water evolution. Arrows indicate source of water. ATLW, warm Atlantic water; AIW, Arctic intermediate water; LAODW, lower Arctic Ocean deep water; GSDW, Greenland Sea deep water; CBDW, Canadian Basin deep water.

environments occurred during the last deglaciatiation and the Holocene. Further, the modern ecology of key species, especially their association with Arctic water masses, suggests these changes were likely due to changes in the location and strength of deepwater formation and the strength of inflowing Atlantic water. More generally, these results emphasize the value of biologic tracers to identify rapid changes in deep ocean circulation that may be especially useful when the isotopic record is complicated by meltwater salinity anomalies, changes in water temperature, and global ice volume changes. It will be especially important in future studies to examine the relationship between faunal indicators and other benthic proxy records such as stable isotopes, to obtain higher sedimentation rate records, and to improve our understanding of species' ecology.

Acknowledgments. We are extremely grateful to the scientists and staff aboard the Polarstern and at the Alfred Wegener Institute, 
Bremerhaven, and GEOMAR, Kiel for allowing us to study the ostracodes from the 1991 and prior cruises. We extend our thanks to $R$. Z. Poore and A. Grantz (USGS) for core tops from the 1992 cruise of the Polarstar to the Northwind Ridge and to L. Polyak (Ohio State University) for core tops from the Russian ice-island cores from the Mendeleyev and Lomonosov Ridges. A. Mackensen (AWI) kindly provided samples from multicores from the 1991 Polarstern cruise containing ostracode softparts. We are grateful to G. Coles and R.C. Whatley for taxonomic comments on Krithe and Acetabulastoma and G. Bonaduce for comments on Cytheropteron testudo. P. Schweitzer was helpful in making the data available through email. S. Ishman and L. Wingard provided helpful reviews of the manuscript. The manuscript benefited greatly from the reviews of G. Jones, R. Maddocks, and P. Steineck. The study was funded by the USGS Global Change and Climate History Program.

\section{References}

Aagaard, K., On the deep circulation in the Arctic Ocean, Deep Sea Res., 28, 251-268, 1981.

Aagaard, K., A synthesis of the Arctic Ocean circulation, Rapp. P.-V. Reun. Cons. Int. Explor. Mer., 188, 11-22, 1989.

Aagaard, K., and E.C. Carmack, The role of sea ice and other fresh water in the Arctic circulation, J. Geophys. Res., 94, 14,485-14,498, 1989.

Aagaard, K, J.H. Swift, and E.C. Carmack, Thermohaline circulation in the Arctic Mediterranean Seas, J. Geophys. Res., 90, 4833-4846, 1985.

Aagaard, K., E. Fahrbach, J. Meincke, and J.H. Swift, Saline outflow from the Arctic Ocean: Its contribution to the deep waters of the Greenland, Norwegian, and Iceland Seas, J. Geophys. Res., 96, 20, 433-20,441, 1991.

Anderson, L.G., G. Bjork, O. Holby, E.P. Jones, G. Kattner, K.P. Koltermann, B. Liljeblad, R. Lindegren, B. Rudels, and J. Swift, Water masses and circulation in the Eurasian Basin: Results from the Oden 91 North Pole Expedition, J. Geophys. Res., 99, 3273-3283, 1994.

Baker, J.H., and J.W. Wong, Paradoxastoma rostratum Sars (Ostracoda, Podocopida) as a commensal on the Arctic gammarid amphipods Gammaracanthus loricatus (Sabine) and Gammarus wilkitzkii Birula, Crustaceana, 14, 307-311, 1968.

Barnard, J.L., Epipelagic and under-ice Amphipoda of the central Arctic Ocean, Sci. Stud. Fletcher's Ice Island, T-3 1952-1955, 1, 115-152, 1959.

Bleil, U., and G. Gard, Chronology and correlation of Quaternary magnetostratigraphy and nannofossil biostratigraphy in NorwegianGreenland Sea sediments, Geol. Rundsch., 78(3), 1173-1187, 1989.

Bonaduce, G., and R. Sprovieri, The appearance of Cytheropteron testudo Sars (Crustacea, Ostracoda) is a Pliocene event. Evidence from a Sicilian sequence (Italy), Boll. Soc. Palaeontol. Ital., 23(1), 131-136, 1984.

Boyle, E.A., Vertical oceanic nutrient fractionation and glacial/interglacial $\mathrm{CO}_{2}$ cycles, Nature, 331, 55-56, 1988.

Boyle, E.A., and L.D. Keigwin, North Atlantic thermohaline circulation during the past 20,000 years linked to high-latitude surface temperature, Nature, 330, 35-40, 1987.

Broecker, W.S., D.M. Peteet, and D. Rind, Does the ocean-atmosphere system have more than one stable mode of operation?, Nature, 315 , 21-26, 1985.

Clark, D.L., R.R. Whitman, K.A. Morgan, and S. Mackey, Stratigraphy and glacial-marine sediment of the Amerasian Basin, Central Arctic Ocean, Spec. Pap. Geol. Soc. Am., 181, 57 pp., 1980.

Cronin, T.M., Bathyal ostracodes from the Florida-Hatteras slope, the Straits of Florida, and the Blake Plateau, Mar. Micropaleontol., 8, 89$119,1983$.

Cronin, T.M., R. Whatley, A. Wood, A. Tsukagoshi, N. Ikeya, E.M.
Brouwers, and W. Briggs Jr., Evidence for elevated mid-Pliocene temperatures in the Arctic Ocean based on marine Ostracoda, Paleoceanography, 8, 161-173, 1993.

Cronin, T.M., T.R. Holtz Jr., and R.C. Whatley, Quatemary paleoceanography of the deep Arctic Ocean based on quantitative analysis of Ostracoda, Mar. Geol., 119, 305-332, 1994.

Dingle, R.C., A.R. Lord, and I.D. Boomer, Deep-water Quatemary Ostracoda from the continental margin off south-western Africa (SE Atlantic Ocean), Ann. S. Afr. Mus., 99(9), 245-366, 1990.

Eisenhauer, A., R.F. Spielhagen, M. Frank, G. Hentzschel, A. Magnini, P.W. Kubik, B. Dittrich-Hannen, and T. Billen, ${ }^{10} \mathrm{Be}$ records of sediment cores from high northern latitudes: Implications for environmental and climatic changes, Earth Planet. Sci. Lett., 124 , $171-184,1994$.

Fairbanks, R.G., A 17,000-year glacio-eustatic sea level record: influence of glacial melting rates on the Younger Dryas event and deep-sea circulation, Nature, 342, 637-642, 1989.

Fütterer, D., Arctic'91: The expedition ARK-VIII/3 of RV "Polarstern" in 1991, Ber. Polarforsch., 107, 1-267, 1992.

Gard, G., Late Quaternary calcareous nannofossil biozonation, chronology, and palaeo-oceanography in areas north of the FaeroeIceland Ridge, Quat. Sci. Rev., 7, 65-78, 1988.

Gard, G., Late Quatemary coccoliths at the north pole: Evidence of icefree conditions and rapid sedimentation in the central Arctic Ocean, Geology, 21, 227-230, 1993.

Gard, G., and J. Backman, Synthesis of Arctic and Sub-Arctic coccolith biochronology and history of North Atlantic drift water influx during the last 500,000 years, in Geological History of the Polar Oceans: Arctic vs Antarctic, NATO ASI Ser. C, vol. 308, edited by U. Bleil and J. Thiede, pp. 417-436, Kluwer Academic, Boston, Mass., 1990.

Jansen, E., and T. Veum, Evidence for two-step deglaciation and its impact on North Atlantic deep ocean circulation, Nature, 343, 612 $616,1990$.

Jones, G.A., and L.D. Keigwin, Evidence from Fram Strait $\left(78^{\circ} \mathrm{N}\right)$ for early deglaciation, Nature, 336, 56-59, 1988.

Jones, G.A., K.L. Elder, and A.R. Gagnon, The use of AMS ${ }^{14} \mathrm{C}$ dating to solve the Central Arctic Ocean chronology problem, Trans. AGU, 75, Ocean Sci. Meet. suppl., 198-199, 1994.

Joy, J.A., and D.L. Clark, The distribution, ecology, and systematics of the benthic Ostracoda of the central Arctic Ocean, Micropalaeontology, 23(2), 129-154, 1977.

Kohler, S.E., and R.F. Spielhagen, The enigma of oxygen isotope stage 5 in the central Fram Strait, in Geological History of the Polar Oceans: Arctic vs Antarctic, NATO ASI Ser. C, vol. 308, edited by U. Bleil and J. Thiede, pp. 489-497, Kluwer Academic, Boston, Mass., 1990.

Lehman, S.J., and S.L. Forman, Late Weichselian glacier retreat in Kongsfjorden, west Spitzbergen, Svalbard, Quat. Res., 37, 139-154, 1992.

Loeng, H., Features of the physical oceanographic conditions of the Barents Sea, Polar Res., 10(1), 5-18, 1991.

Nowaczyk, N.B. and M.Baumann, Combined high resolution magnetostratigraphy and nannofossil biostratigraphy for late Quaternary Arctic Ocean sediments, Deep Sea Res., 39 (Suppl. Iss. 2A), S567-S601, 1992.

Nowaczyk, N.R., T.W. Frederichs, A. Eisenhauer, and G. Gard, Magnetostratigraphic data from late Quaternary sediments from the Yermak Plateau, Arctic Ocean: Evidence for four geomagnetic polarity events within the last 170 kyrs of the Brunhes Chron, Geophys.J. Int', in press, 1995.

Oppo, D.W., and R.G. Fairbanks, Variability in the deep and intermediate water circulation of the Atlantic Ocean: Northern Hemisphere modulation of the Southern Hemisphere, Earth Planet. Sci. Lett., 86, 1-15, 1987.

Overpeck, J.T., T. Webb III, and I.C. Prentice, Quantitative interpretation of fossil pollen spectra: Dissimilarity coefficients and the method of modern analogs, Quat. Res., 23, 87-108, 1985. 
Pagels, U., Sedimentologische Untersuchungen und Bestimmungen der Karbonatlosung in spatiquartaren Sedimenten des ostlichen Arktischen Ozeans. GEOMAR Rep, 10, 106 pp., 1991.

Phillips, R.L., Sediment and sediment processes in the Arctic, Arctic Res. U.S., 8, 53-62, 1994.

Poore, R.Z., R.L., Phillips, and H.J.Rieck, Paleoclimate record for Northwind Ridge, western Arctic Ocean, Paleoceanography, 8(2), 149-160, 1993.

Reid, J.L., On the contribution of the Mediterranean Sea outflow to the Norwegian-Greenland Sea, Deep Sea Res., Part A, 26, 1199-1223, 1979.

Rudels, B., The O-S relations in the northern seas: Implications for deep circulation, Polar Res., 4, 133-159, 1986.

Rudels, B. The formation of Polar Surface Water, the ice export and the exchange through the Fram Strait, Prog. Oceanogr., 22, 205-248, 1989.

Rudels, B., and D. Quadfasel, Convection and deep water formation in the Arctic Ocean-Greenland Sea system, J. Mar. Sys., 2, 435-450, 1991.

Schornikov, E.I., Acetabulastoma, a new genus of ostracodes, Zool. Zhum., 49, 1132-1143, 1970.

Scott, D.P., P.J. Mudie, V. Baki, K.D. MacKinnon, and F.E. Cole, Biostratigraphy and late Cenozoic paleoceanography of the Arctic Ocean: Foraminiferal, lithostratigraphic, and isotopic evidence, Geol. Soc. Am. Bull., 101, 260-277, 1989.

Slowey, N.C., and W.B. Curry, Enhanced ventilation of the North Atlantic subtropical gyre thermocline during the last glaciation, Nature, 358, 665-668, 1992.

Spielhagen, R., and H. Erlenkeuser, Stable oxygen and carbon isotopes in planktic foraminifers from Arctic Ocean surface sediments: Reflections of the low salinity surface water layer, Mar. Geol., 119, 227-250, 1994.

Stein, R., C. Schubert, H. Grobe, and D. Fütterer, Late Quaternary changes in sediment composition in the central Arctic Ocean: First results of the Arctic'91 expedition, in Proceedings of the International Conference on Arctic Margins, edited by D. K. Thurston, Alaska Geological Society, Anchorage, 1993.

Stein, R., C. Schubert, C. Vogt, and D. Fütterer, Stable isotope stratigraphy, sedimentation rates, and salinity changes in the latest Pleistocene to Holocene eastern central Arctic Ocean, Mar. Geol., $119,333-355,1994$ a.
Stein, R., S.-I. Nam, C. Schubert, C. Vogt, D. Fütterer, and J. Heinemeier, The last deglaciation event in the eastern central Arctic Ocean, Science, 264, 692-696, 1994b.

Stein, R., H. Grobe, and M. Wahsner, Organic carbon, carbonate, and clay mineral distributions in eastern central Arctic Ocean surface sediments, Mar. Geol., 119, 269-285, 1994c.

Swift, J.H., and K.P. Koltermann, The origin of Norwegian Sea deep water, J. Geophys. Res., 88, 5981-5986, 1988.

Veum, T., E. Jansen, M. Arnold, I. Beyer, and J.-C. Duplessy, Water mass exchange between the North Atlantic and the Norwegian Sea during the past 28,000 years, Nature, 356, 783-785, 1992.

Whatley, R.C., Littoral and sublittoral Ostracoda from Sisimiut, West Greenland, in Report of the 1979 Greenland White-fronted Goose Study Expedition to Eqalungmint Nunal, West Greenland, edited by A.D. Fox and D.A. Stroud, pp. 269-284, University of Wales Press, Aberystwyth, U.K., 1982.

Whatley, R.C. and G. Coles, The late Miocene to Quaternary Ostracoda of Leg 94, Deep Sea Drilling Project, Rev. Espan. Micropaleontol., $19(1), 33-97,1987$.

Whatley, R.C. and M. Eynon, Ostracoda from the Greenland Sea, Micropalaeontology, in press, 1995.

Zahn, R., B. Markussen, and J. Thiede, Stable isotope data and depositional environments in the late Quaternary Arctic Ocean, Nature, 314, 433-435, 1985.

Zahn, R., M. Sarnthein, and H.Erlenkeuser, Benthic isotope evidence for changes of the Mediterranean outflow during the late Quaternary, Paleoceanography, 2, 543-559, 1987.

T. M. Cronin and T. R. Holtz,Jr., U.S. Geological Survey, Reston, VA 22092. (e-mail: tcronin@geochange.er.usgs.gov)

D. Fütterer, R. Stein, and J. Wollenburg, Alfred Wegener Institute for Polar and Marine Research, Bremerhaven, Germany.

R. Spielhagen, GEOMAR Research Center for Marine Sciences, University of Kiel, Wischhofstraße 1-3, D-24148 Kiel, Germany

(Received May 4, 1994; revised November 29, 1994; accepted November 29, 1994) 